This item was submitted to Loughborough's Research Repository by the author.

Items in Figshare are protected by copyright, with all rights reserved, unless otherwise indicated.

\title{
Inferring air-water temperature relationships from river and catchment properties
}

PLEASE CITE THE PUBLISHED VERSION

http://dx.doi.org/10.1002/hyp.9842

\section{PUBLISHER}

(c) John Wiley \& Sons, Ltd.

\section{VERSION}

AM (Accepted Manuscript)

\section{PUBLISHER STATEMENT}

This work is made available according to the conditions of the Creative Commons Attribution-NonCommercialNoDerivatives 4.0 International (CC BY-NC-ND 4.0) licence. Full details of this licence are available at: https://creativecommons.org/licenses/by-nc-nd/4.0/

\section{LICENCE}

CC BY-NC-ND 4.0

\section{REPOSITORY RECORD}

Johnson, Matthew F., Robert L. Wilby, and Julia Toone. 2019. "Inferring Air-water Temperature Relationships from River and Catchment Properties”. figshare. https://hdl.handle.net/2134/16257. 


\section{Inferring air-water temperature relationships from river}

2 and catchment properties

3

4 Johnson $\mathrm{MF}^{1}$, Wilby $\mathrm{RL}^{1}$, Toone, $\mathrm{JA}^{2}$

5

$6{ }^{1}$ Department of Geography, Loughborough University, Leicestershire, LE11 3TU, UK.

7 Email: m.f.johnson@lboro.ac.uk; r.l.wilby@lboro.ac.uk

8

$9 \quad 2$ Environment Agency, Trentside Office, Nottingham, NG2 5FA, UK.

10 Email: julia.toone@environment-agency.gov.uk

This is the peer reviewed version of the following article:

Johnson, M.F., Wilby, R.L. and Toone, J.A. 2014. Inferring air-water temperature relationships from river and catchment properties. Hydrological Processes, 28, 2912-2928.

which has been published in final form at:

http://onlinelibrary.wiley.com/doi/10.1002/hyp.9842/abstract.

This article may be used for non-commercial purposes in accordance With Wiley Terms and Conditions for self-archiving. 


\section{Abstract:} 0

Water temperature (Tw) is a key determinant of freshwater ecosystem status and cause for concern under a changing climate. Hence there is growing interest in the feasibility of moderating rising Tw through management of riparian shade. The Loughborough University TEmperature Network (LUTEN) is an array of 36 water and air temperature (Ta) monitoring sites in the English Peak District set up to explore the predictability of local Tw, given Ta, river reach, and catchment properties. Year one of monitoring shows that 84 to $94 \%$ of variance in daily Tw is explained by Ta. However, site-specific logistic regression parameters exhibit marked variation and dependency on upstream riparian shade. Perennial spring flows in the lower River Dove also affect regression model parameters and strongly buffer daily and seasonal mean Tw. The asymptote of the models (i.e., maximum expected Tw) is particularly sensitive to groundwater inputs. We conclude that reaches with spring flows potentially offer important thermal refuges for aquatic organisms against expected long-term warming of rivers and should be afforded special protection.

Key words: climate change; water temperature; riparian shade; logistic regression; springs 


\section{INTRODUCTION}

Water temperature (Tw) has major ecological significance, not least for water quality (through dissolved oxygen levels and reaction rates), and hence for compliance with environmental regulation (such as the European Union Water Framework Directive). In addition, Tw variation and duration above critical thresholds affect fish behaviour and survival (Elliott et al., 1995; Jonsson et al., 2001; Webb and Walsh, 2004; Hari et al., 2006; Wehrly et al., 2007). Tw also influences the growth, metabolism and timing of emergence of aquatic invertebrates (Briers et al., 2004; Durance and Ormerod, 2007). Over the next century, air temperature (Ta) is expected to rise and with it Tw (Hulme et al., 2002; Kaushal et al., 2010; van Vleit et al., 2012). Higher mean and peak Tw could cause harm to ecological communities in freshwaters and has, consequently, attracted the attention of regulatory bodies such as the Environment Agency (2012). As a result, there is growing interest in the thermal dynamics of rivers, in particular, the spatial and temporal variability of Tw, and ways of alleviating rising temperatures by, for example, creating thermal refugia or identifying habitats that are particularly susceptible to heat stress.

The most important controls of river Tw are solar radiation and discharge. The former governs the diurnal and seasonal variations in thermal energy. The latter reflects the dominant hydrological pathways and thermal inertia (due to mass) of water heated (Poole and Berman, 2001). Other natural sources of heat, for example, generated by channel-bed friction or flux due to liquid precipitation, are relatively minor in most fluvial systems (Webb and Zhang, 1997; Hannah et al., 2008; Webb et al., 2008; Ouellet et al., 2012). In addition, Tw is strongly affected by temporal and spatial variations in discharge linked to the annual water cycle and tributary flows. Hyporheic (near surface) and phreatic (deep groundwater) inputs add further to the heterogeneity (Constantz, 1998; O’Driscoll and DeWalle, 2006). Phreatic sources typically have relatively constant $\mathrm{Tw}$ and can have a more damped response to climate variations than the hyporheic contributions to channel flow. Overall, in the absence of major tributaries and spring flows, Tw generally increases with distance downstream as the water body experiences net gains of radiant energy.

It is not feasible to monitor energy budget components for long periods or at all points in a river network. For instance, remotely sensed, thermal imagery provides high spatialresolution but only snap-shots of Tw in time (e.g., Torgesen et al., 2001). Therefore, spatially and temporally varying Tw is often estimated from deterministic or statistical models using 
basic meteorological and hydrological information (Yonus et al., 2000; Johnson, 2003; Caissie, 2006; Lee et al., 2012). Although air-water temperature relationships are typically strong, the correspondence is not direct as Ta has a small effect on sensible heat flux (Stefan and Preud'homme, 1993; Webb and Nobilis, 1997; Johnson, 2003). Instead, the correlation between Ta and Tw is due to incoming solar radiation and outgoing long-wave radiation simultaneously affecting the thermal dynamics of air and water bodies. The power of this relationship is strongest at monthly- and weakest at sub-daily time-scales (Stefan and Preud'homme, 1993; Caissie, 2006) as other factors, such as riparian shading, become increasingly important.

Linear regression analysis is widely used to model Tw from Ta (e.g., Mackey and Berrie, 1991; Stefan and Preud'homme, 1993; Imholt et al., 2012). However, the Ta-Tw relationship is known to depart from linearity at extreme Ta. Vapour pressure grows near-exponentially as temperature increases evaporation and latent cooling thereby imposing an upper limit on Tw in rivers (Mohseni et al., 2002). Non-linearity at low air temperatures arises because Tw is buffered by hyporheic and phreatic water and only freezes when Ta drops substantially below $0^{\circ} \mathrm{C}$ (Crisp and Howson, 1982). As a result of these effects, Mohseni et al. (1998) assert that the relationship between weekly Ta and Tw is best described by a logistic function.

Although discharge and solar radiation are the main drivers of $\mathrm{Tw}$, there are many other catchment and meteorological influences on Tw dynamics. For example, shading of water by cloud cover, the landscape and riparian vegetation reduces warming by solar radiation (Rutherford et al., 2004; Malcolm et al., 2008). Previous studies have identified factors that control Tw regimes at a range of scales and these are often used as dependent variables in regression models of Tw (Webb and Walling, 1986; Lewis et al., 2000; Rutherford et al., 2004; Bourque and Pomeroy, 2001; Malcolm et al., 2008; Webb et al., 2008; Hrachowitz et al., 2010). These include the geological, hydrological, topographic and climatic characteristics of the catchment as well as anthropogenic alterations to land use, river regime and thermal loads.

Of particular interest and potential importance to $\mathrm{Tw}$ is the shade afforded by riparian vegetation, which may moderate warming under a changing climate. Riparian vegetation reduces the amount of solar radiation reaching the channel and limits heat exchange with the atmosphere by reducing wind speeds and decreasing convection and advection from the water 
surface (Naiman et al., 1992; Li et al., 1994; Story et al., 2003; Rutherford et al., 2004; Moore et al., 2005). The potential for vegetation to reduce Tw has been shown by experimental studies. For example, Johnson (2004) artificially shaded a $200 \mathrm{~m}$ reach of river in HJ Andrews Experimental Forest, Oregon, USA and found that under full sun there was a net energy gain of $580 \mathrm{~W} \mathrm{~m} \mathrm{~W}^{-2}$ but under full shade there was a net loss of $149 \mathrm{~W} \mathrm{~m}^{-2}$. However, establishment and maintenance of riparian vegetation can be expensive and carries some risk by increasing channel roughness and local flood levels. Flood hydraulics may also be affected by large woody debris that can damage or build-up behind structures, impeding the flow. However, riparian vegetation has many ecological benefits (Everall et al., 2012), and is increasingly regarded as an attractive option for thermal management of freshwater systems (Environment Agency, 2012).

Sites susceptible to Tw change or conducive to management need to be identified in order to maintain favourable thermal conditions for existing freshwater ecosystems. The Loughborough University TEmperature Network (LUTEN) is a dense array of Ta and Tw monitoring sites in the English Peak District set up with these practical needs in mind (Toone et al., 2011; Wilby et al., 2012). This paper uses data from LUTEN to test methods of predicting Tw at reach-scales (metres) from spatially coarse Ta measurements, air-water temperature relationships, and catchment properties. We intentionally keep data requirements to a minimum to mimic the information that might be available to field officers and management agencies. First, we describe measured Ta and Tw dynamics, and correlations within the Rivers Dove and Manifold. Second, we evaluate regression models for predicting Tw from Ta measured at instrumented sites. Third, we assess the extent to which regression model parameters can be inferred from reach and catchment properties. We conclude with a discussion of the importance of vegetation and hydrological controls on thermal refuges in the rivers.

\section{FIELD SITES AND DATA}

\section{Catchment characteristics and instrumented reaches}

The instrumented reaches of the River Dove and Manifold have catchment areas of $131 \mathrm{~km}^{2}$ and $75 \mathrm{~km}^{2}$ respectively. Both river channels are of similar dimensions, ranging from 1-12 m in width. The catchments are adjacent with comparable meteorological conditions, including average annual precipitation in excess of $1000 \mathrm{~mm} /$ year. Both rivers are situated in an upland area with altitude range of $154 \mathrm{~m}$ (at their confluence) to $450 \mathrm{~m}$ above sea level. Both run 
predominately through gravel drift deposits underlain by mudstone, siltstone and sandstone of the Millstone grit group. The River Dove also flows parallel to an outcrop of Carboniferous limestone for much of its length and both rivers eventually intersect this outcrop at their downstream ends (Figure 1). The headwaters are characterised by relatively open valleys whereas downstream limestone reaches feature deep gorge sections. The limestone outcrop denotes a zone of substantial groundwater inputs, including several large non-thermal and semi-thermal springs (Edmunds, 1971; Abesser and Smedley, 2008).

Both catchments are predominantly moorland and grazed pasture, stocked with cattle and sheep. Woodland constitutes only $5 \%$ of the catchment area but there are reaches with substantial tree cover of predominantly Ash (Fraxinus excelsior), particularly in the Dove. The rivers are highly sinuous but some reaches have been artificially straightened to protect agricultural land (Dalton and Fox, 1988; Rice and Toone, 2010). This is particularly evident in the Manifold which has actively eroding banks at many sites, requiring revetments and makeshift bank protection by land-owners. In addition, flows in the lower reaches of the River Dove (sites D17 to D24) are affected by more than 100 weirs. Most are less than $0.5 \mathrm{~m}$ high and were installed to increase the feeding area for trout to benefit anglers. A summary of key channel and landscape metrics is presented by Table 1 .

\section{Deployment and accuracy of temperature sensors}

LUTEN consists of 36 sites with average spacing $1.7 \mathrm{~km}$ along the Rivers Dove and Manifold in the English Peak District (Figure 1). At each site, both Ta and Tw are continuously monitored using Gemini Tinytag Aquatic 2 thermistor data loggers. Tw is monitored by loggers attached to weights that are buried in riffles so that the instrument is flush with the river bed surface. Previous work suggests that the effect of bed conduction is minimal (Neilson et al., 2009). Ta is monitored via Tinytag thermistors attached to the north face of a tree close to the Tw sensor, approximately $2 \mathrm{~m}$ above the water surface. This logger array has been recording temperature every 15 minutes since $1^{\text {st }}$ March 2011.

Tinytag thermistors are factory calibrated and tested. Nonetheless, we checked the calibration and consistency of readings between sensors by performing additional tests. A set of fielddeployed sensors was placed in a shaded, controlled environment subject to natural diurnal water temperature cycles. Over the course of five days the largest discrepancy in maximum 15-minute Tw between the sensors was $0.2{ }^{\circ} \mathrm{C}$ (standard error $=0.03{ }^{\circ} \mathrm{C}$ ). Daily mean and 
maximum values did not differ by more than $0.1{ }^{\circ} \mathrm{C}$. In addition, a Fisher Scientific Traceable Digital Thermometer with $0.05^{\circ} \mathrm{C}$ accuracy was used to check a further five sensors and, all were within $0.15{ }^{\circ} \mathrm{C}$ of the Tinytag Tw. Spot checks of Tw are also made at each data download (approximately four times per year) to further check logger accuracy. Overall, we confirm the manufacturer's view that thermistor accuracy is within $\pm 0.2{ }^{\circ} \mathrm{C}$.

Practices for shielding thermistors from solar radiation vary enormously (even between studies published by Hydrological Processes). Some place temperature probes within white PVC tubing to prevent direct exposure to sunlight (Hrahowitz et al., 2010); some stake unshielded sensors to the channel substrate (Broadmeadow et al., 2011) or glue them to large rocks (Isaak and Horan, 2011); others do not explicitly mention shielding (Hannah et al., 2008). We considered the range of options and took a middle approach. Although our sensors were not artificially shielded, they were carefully obscured by local cliff faces, channel shade and riparian cover to minimise the influence of direct solar radiation, as well as the risk of theft or interference. Moreover, the wider landscape provides deep shade for much of the year at many sites (Table 1).

We also tested the effect of tube shielding under laboratory conditions with and without flow, for clear, shallow $(20 \mathrm{~cm})$ water, with a $100 \mathrm{~W} \mathrm{~m}^{-2}$ light source directly overhead. Under these extreme conditions maximum and mean differences between shielded and unshielded sensors were respectively $0.15{ }^{\circ} \mathrm{C}$ and $0.12{ }^{\circ} \mathrm{C}(n=12)$ for still water. Under steady flow conditions $\left(0.2 \mathrm{~m} \mathrm{~s}^{-1}\right)$ within a flume the corresponding values were $0.05{ }^{\circ} \mathrm{C}$ and $0.03{ }^{\circ} \mathrm{C}$ ( $n=12)$ (Johnson and Wilby, 2013a). In 6 out 12 flume runs, the shielded sensor was marginally warmer than the unshielded device (reflecting the limits of inter-sensor accuracy). Therefore, given the micro-siting precautions, and assessed shielding effects, we conclude that our Tw measurements are still accurate to within the manufacturer's range of $\pm 0.2{ }^{\circ} \mathrm{C}$.

Unshielded Ta sensors attached to the north side of trees are potentially affected by micrometeorological factors, and periods of direct solar radiation. Orbital geometry determines that at the latitude of the Dove and Manifold the sun is in the northern hemisphere for less than $10 \%$ of the time and, even then, at a low angle above the horizon When taking into account local landscape and canopy shading, the risk of direct heating of sensors is reduced still further. The large number of Ta sensors enables cross-checking between sites, and quality assurance was performed using data from the nearest Met Office station (Buxton, $53^{\circ} 15^{\prime} \mathrm{N}, 1^{\circ} 55^{\prime} \mathrm{W}$ ). 
The elevations of D3 and Buxton (307 m) are almost identical as are their respective mean annual air temperatures: $9.0^{\circ} \mathrm{C}$ and $9.3^{\circ} \mathrm{C}$ respectively (see Table 1 ).

Correlation coefficients for maximum daily Ta at Buxton versus LUTEN range from 0.89 to 0.97 in the Dove, and from 0.92 to 0.97 in the Manifold. The largest anomalies at our two reference sites (see below) are all cool biases (i.e., higher Ta are recorded at Buxton than on the river side). These differences can be interpreted in several ways: a modest heat island effect at Buxton; local variations in cloud cover or precipitation; katabatic winds and other micro-meteorological effects in the deep limestone gorges; or cooling by vegetation. However, occasional cool outliers in LUTEN Ta are not consistent with direct solar heating of sensors. Hence, we conclude that our Ta and Tw measurements are fit for the purpose of interpreting water temperature variations within the two catchments.

Following the protocols recommended by Sowder and Steel (2012), downloaded Ta and Tw data were visually checked for missing data and gross outliers. During April and May 2011, three sites in the Manifold had very low flow, leaving loggers exposed. This was apparent from the convergence of Tw and Ta values. Typically, Tw data from submerged loggers have daily ranges between 20 to $50 \%$ of the Ta range, whereas exposed sites had ranges between $70 \%$ and $100 \%$ the Ta range. Therefore, any Tw data with ranges $>70 \%$ of Ta were deemed to be de-watered and flagged as suspect. Some sensors were later lost during high flow episodes in autumn 2011 and winter 2011/12, leaving gaps in the record. Sensors with less than $90 \%$ complete record were excluded from further analysis.

\section{Environmental characteristics of monitored reaches}

The environmental characteristics of reaches between monitoring sites were quantified using field and desk-based techniques (Table 1). Bank full width and depth were collected during a fluvial audit of the rivers by Rice and Toone (2010) and were averaged for the river reaches falling between our monitoring stations (Figure 1). Distance from source was defined as the channel length between the monitoring site and river source, estimated from a GIS model and field-validated Ordnance Survey maps. Site altitude, reach length, sinuosity, and channel slope were determined from the same GIS-model, which incorporates a $5 \mathrm{~m}$ resolution Digital Elevation Model (DEM). Following Hannah et al (2008) upstream catchment area was used as a proxy for gauged river flow. 
Two metrics of topographic shade were generated using the DEM and solar geometry: the percentage of time monitoring sites were exposed to direct solar radiation; and the percentage of potential solar irradiance that reaches the channel each year (Johnson and Wilby, 2013b). Note that differences between time in shade and potential irradiance arise because shading mainly occurs at low solar angles, when there is less solar radiation. Note also that this metric of topographic shade does not capture micro-scale features, such as channel banks, or variations in cloud cover and water vapour which potentially reduce the amount of light received. Consequently, the values in Table 1 should be viewed as the maximum possible potential irradiance of each site and lower bound for time in shade.

Shading by vegetation was assessed using aerial photographs overlaid onto Ordnance Survey maps in the GIS model. The length of river reach between monitoring sites that fell into each of the following four, discrete categories of riparian shade was measured (Figure 2):

1. None: the channel is clearly visible from photographs and has no riparian shade.

2. Patchy: the channel is visible but discontinuous tree cover occurs along the banks.

3. Linear: the channel is partly obscured by narrow bands (or single lines) of trees along the banks.

4. Complete: the channel is entirely concealed by continuous, dense tree cover on the banks.

The four groups were merged into two categories for later analysis. The first, 'open', includes 'none' and 'patchy'; the second, 'shaded', includes 'linear' and 'complete'. A distinction is made between local and cumulative shade. Table 1 reports the local riparian cover, defined as the percentage of upstream reach length classified as shaded. This differs from cumulative shade which is the percentage of total upstream lengths classified as shaded. Both are employed in the correlation analysis below.

The influence of groundwater on Tw in the lower Dove was surveyed at sites in the main channel and at visible spring heads (Figure 3). Conductivity, $\mathrm{pH}$ and Tw were obtained from spot measures at monitoring sites every three months during the first year of monitoring (March 2011 to February 2012) (Table 1). In addition, spot measures were made upstream, downstream and within known spring flows every other month since July 2012. Although a considerable volume of flow is assumed to be gained by the main channel from groundwater (Edmunds, 1971), only substantial surface springs were monitored. The exceptionally wet summer and autumn of 2012 provided a rare opportunity to locate active springs, including 
some that are not shown on Ordnance Survey maps. Furthermore, we cross-compared our inventory of surface springs with other surveys of the Dove (Edmunds, 1971; Brassington, 2007; Abesser and Smedley, 2008).

All the variables listed in Table 1 were correlated with the parameters of regression models for Tw based on Ta, computed below.

\section{STATISTICAL METHODS}

\section{Regression analysis}

Linear and logistic regression models were calibrated using 12 months of daily-mean and daily-maximum Ta and Tw since 1 March 2011. The form of the logistic regression is a three-parameter model following Mohensi et al. (1998):

$$
T w=\frac{\alpha}{\left(1+\exp ^{\gamma(\beta-T a)}\right)}
$$

The three logistic regression parameters $\alpha, \beta$, and $\gamma$ are all physically interpretable and have units in ${ }^{\circ} \mathrm{C}$. The upper asymptote $(\alpha)$ of the model is the maximum Tw that the model can predict. The inflection point of the curve $(\beta)$ represents the region of Ta with the greatest rate of change of Tw. The gradient of the model at the inflection point $(\gamma)$ gives the day to day increase of Tw for a unit increase in Ta. The value of these parameters is hypothesised to be dependent on the environmental and thermal characteristics of the upstream river network. Consequently, the three regression parameters at each site were correlated with reach and catchment properties to determine whether generalised patterns might exist.

\section{Spatial and temporal autocorrelation analyses}

The Durbin-Watson test was used as a diagnostic of autocorrelation in regression model residuals. In addition, daily-maximum Ta and Tw were investigated for inter-site correlations. Tw at each site was correlated against Tw measured at all other sites and plotted against the separation distance between sites (Figure 4). This was also repeated for Ta in order to assess the level of heterogeneity in temperature along the river network.

The spatial homogeneity of Ta (see Figure 4) supports the view that regression models can be built using a single representative record rather than local Ta series. On the Dove, site D10 
was considered the most representative Ta series as this site has the highest average correlation with other Ta measures ( $r=0.95$ to 0.99 ). On the Manifold, M8 was the most representative. Hence, logistic regression was performed using these single, representative Ta series as independent variables and site-specific Tw measures as dependent variables.

\section{RESULTS}

\section{Regression model evaluation}

The weakest linear regression model explains $78 \%$ of the variance $\left(\mathrm{R}^{2}\right)$ in daily mean Tw at site D18 (Table 2). The logistic model was consistently better at relating daily Tw to Ta at all sites. As maximum Tw are considered to be of greater ecological significance they are used in all subsequent analysis of the logistic regression model. The $\mathrm{R}^{2}$ of these models range from $87 \%$ to $94 \%$ and values of the three regression parameters are given in Table 3 . Figure 5 shows examples of logistic regression models at illustrative sites in the Dove.

The Durbin-Watson statistic confirms that there is positive, first-order autocorrelation in regression model residuals (Figure 6). Clear seasonal variations in residuals emerge with models consistently under-estimating summer Tw and over-estimating winter Tw. The residuals are not correlated with river discharge but there is a spatial signature. In general, downstream sites are more affected by autocorrelation than upstream sites. However, there are exceptions to this trend in both rivers and the River Dove is more heterogeneous in terms of autocorrelation than the Manifold (Figure 7). In particular, there are step changes in intersite correlation at sites D11, D16 and D23.

All regression models were validated using daily Tw over the first five months of the second year of data collection (1 March 2012 onwards). April to July 2012 was the wettest on record for England and Wales (going back to 1766) with more than 200\% the 1971-2000 average precipitation (CEH, 2012). This produced high river flows for extended periods. Despite these extreme conditions, the models performed well at all sites, with $\mathrm{R}^{2}$ between 0.60 and 0.90, and an average reduction in explained variance between the calibration and validation periods of 0.12 (Table 3). Note that autocorrelation effectively reduces the sample sizes of the regression models so the reported $\mathrm{R}^{2}$ statistics should be interpreted as upper bound. The average standard error of the logistic model was $1.3^{\circ} \mathrm{C}$ for calibration and $1.7^{\circ} \mathrm{C}$ for validation. 
Plots of predicted versus observed Tw during the validation period had slopes between 0.40 and 1.04 and intercepts typically in excess of $2^{\circ} \mathrm{C}$. Further analysis of the best fit line reveals that most models over-estimate Tw below $8^{\circ} \mathrm{C}$ and under-estimate Tw above $8^{\circ} \mathrm{C}$. However, this is location specific with sites in the Manifold generally over-predicting a greater range of temperatures. There are also exceptions, such as D4, which over-estimates all temperatures above $0^{\circ} \mathrm{C}$. In addition, Tw appears to be over-estimated by the model during high flow events at the most downstream sites.

\section{Spatial and temporal variations in Ta and Tw}

Daily-mean Tw follows the anticipated seasonal trend of highest values in summer and lowest during winter. Summer Tw is usually cooler than Ta; conversely during winter Tw often exceeds Ta. When averaged across the entire year, Tw is greater than Ta at all sites with the exception of D4 and M2 (Table 1). Differences between mean Tw and Ta are partly explained by missing data. However, differences are also expected given the hydrogeology of the region. Several sources mention geothermal heating of deep groundwater and semithermal springs in the Dove (Edmunds, 1971; Gunn et al., 2006; Brassington, 2007; Abesser and Smedley, 2008). Table 4 provides an inventory of ephemeral and perennial springs identified from repeat field surveys and secondary sources. The semi-thermal spring at Beresford Dale (S9 in Table 4, near D17 in Table 1) stands out from the other surface springs which typically have Tw in the range 8 to $10^{\circ} \mathrm{C}$. Downstream of D17, thermal inertia, semithermal groundwater inflow, and ponding behind weirs could all be contributing to elevated Tw compared with Ta.

Contrary to expectations, there is no clear increase in Ta with distance downstream despite a decline in altitude of nearly $200 \mathrm{~m}$. However, there is a general downstream rise in Tw in both rivers. The annual range of Tw also increases with distance downstream and is greater for sites on the Manifold than the Dove (Figure 8). The greatest range was $22.8^{\circ} \mathrm{C}$ at M16 with a minimum temperature of $0.1^{\circ} \mathrm{C}$ on 4th February 2012 and a maximum of $22.9^{\circ} \mathrm{C}$ on 15th July 2011. The downstream increase in Tw range is interrupted at a number of sites and, when disaggregated by season, declines with distance downstream in winter and spring. The greatest reduction in Tw range is at the most downstream site on the Dove (D23) where Tw range is only $8.0^{\circ} \mathrm{C}$. This is attributed to the buffering of Tw by perennial groundwater flows upstream of this site. 
371 As noted above, Ta and Tw were relatively homogenous along both rivers (Figure 4). In the Manifold inter-site correlations (r) for Tw were greater than 0.98 and more homogenous than Ta. The Dove has slightly lower correlations but still above 0.90 for Tw, and 0.92 for Ta. Therefore, Tw in the Dove is more spatially heterogeneous than in the Manifold, with D23 in particular being thermally distinct from upstream sites (Figure 4, open circles).

\section{Estimation of logistic parameters from environmental characteristics}

Regression models have strong explanatory power, but it is clear from Table 3 that models are site-specific because they have substantially different parameters for each location. As reported by Mohensi et al. (1998), $\alpha$ and $\beta$ are strongly correlated ( $r=0.95)$ and, therefore, only one needs to be related to environmental parameters in order to generalise the regression model. Conversely, $\gamma$ is not correlated with the other parameters and must be independently related to environmental factors. Most catchment characteristics in Table 1 were weakly or uncorrelated with regression parameters. This includes distance from source and altitude (respectively $r=0.49$ and 0.46 ), implying that regression parameters do not follow simple downstream trends in these rivers. The only statistically significant $(p<0.001)$ relationship identified was between $\gamma$ and cumulative downstream riparian shade (Figure 9). In contrast, riparian shade had weak explanatory power in relation to both $\alpha$ and $\beta\left(\mathrm{R}^{2}=0.3\right.$ and 0.2 , respectively). Toone et al. (2011) previously noted a link between weaker forcing of Tw by Ta at sites with low turbidity (a proxy for groundwater inflow).

\section{DISCUSSION}

\section{Spatial and temporal heterogeneity of Tw}

Seasonal variations in Ta and Tw are evident at all sites, although these are less pronounced in areas of groundwater input, and near river sources. Perennial buffering by groundwater, particularly at site D23, substantially alters the thermal regime, reducing the range in Tw. At site $\mathrm{D} 23$, the annual range of $\mathrm{Tw}$ is only $8^{\circ} \mathrm{C}$ compared with $16^{\circ} \mathrm{C}$ at $\mathrm{D} 22$, just $1.5 \mathrm{~km}$ upstream. Surveys of water emanating from springs in Dovedale show relatively constant temperature, reducing both daily and seasonal variations in Tw (Figure 3), consistent with other studies (Webb and Zhang, 1999; Story et al., 2003; O’Driscoll and DeWalle, 2006).

Our surveys suggest that the transition between perennial and ephemeral spring flow occurs around 200 metres above sea level (Table 4). Upstream of D20, Tw is raised in winter by relatively warm spring flows (S1 to S10); conversely there is no cooling effect in summer 
when spring flow ceases. This has the net effect of raising annual average Tw (see Table 1). The different regimes of ephemeral and perennial springs may also explain the lack of correlation between conductivity (an indicator of spring flow) and regression parameters. The input of groundwater acts much the same as the input of water from tributaries, creating a discontinuity in downstream trends, and increasing spatial heterogeneity of the thermal regime, as evidenced by the lower inter-site correlations in the Dove (Figure 4).

The Manifold exhibits marked seasonal and longitudinal patterns in Tw, with high similarity between sites, whereas the Dove is more complex both temporally and spatially. For example, the difference in annual-mean maximum Tw between the most upstream and downstream sites in the Manifold indicates Tw increases by $0.05{ }^{\circ} \mathrm{C} / \mathrm{km}$. In summer (June to August) the warming is $0.14{ }^{\circ} \mathrm{C} / \mathrm{km}$ and in winter (December to February) it is $0.05{ }^{\circ} \mathrm{C} / \mathrm{km}$. However, in the Dove, there is a cooling rather than warming trend due to the local groundwater effects at site D23. If the same analysis is performed for sites D1 to D22, immediately upstream of D23, the warming trend is $0.06{ }^{\circ} \mathrm{C} / \mathrm{km}$ for the whole year, $0.11^{\circ} \mathrm{C} / \mathrm{km}$ in summer and $0.03{ }^{\circ} \mathrm{C} / \mathrm{km}$ in winter (see Figure 8).

The similarity between the Dove and Manifold is expected given the catchments are relatively small and adjacent. Nonetheless, these findings need to be viewed with caution as the positioning of sites will affect the results as the Manifold is monitored for a shorter length that begins $3.6 \mathrm{~km}$ from the river's source, in comparison to the Dove which is monitored from only $1.8 \mathrm{~km}$ from the source. Although our results support findings of other studies showing that spatial variations in Tw are most pronounced in summer (Imholt et al., 2012), our values are relatively low compared with other small- to medium-sized rivers (3 to $15 \mathrm{~m}$ width) which warm by $0.07^{\circ} \mathrm{C} / \mathrm{km}$ (Torgersen et al., 2001) to $0.6^{\circ} \mathrm{C} / \mathrm{km}$ (Zwieniecki and Newton, 1999). These differences may reflect site locations as well as regional variations in catchment and meteorological properties.

\section{Regression model skill}

Linear Ta-Tw regressions have strong explanatory power that is only marginally less than the three-parameter, logistic regression reported elsewhere (e.g. Mohensi et al., 1998). In addition, $\alpha$ - and $\beta$-parameters in the logistic regression are strongly correlated $(r=0.95)$, which questions the value of a three parameter model. However, linear regression does not reflect the non-linear physical relationship between solar radiation and Tw as the former 
implies that Tw never reaches an upper or lower asymptote for extreme Ta. In the context of

440 climate change, extreme Tw values are often of great interest and it is at the end members that differences between the linear and logistic regression models are most pronounced.

Predicting Tw from Ta using regression-based models is straightforward for the studied rivers. The homogeneity of Ta across the catchments also meant that there was little benefit in using site-specific Ta measurements to predict Tw. Instead, single Ta measurements were representative of the whole catchment because of strong inter-site correlations and therefore could be used with equal success as site-specific measures (as indicated by the small differences in $\mathrm{R}^{2}$ values between Tables 2 and 3).

The Durbin-Watson test confirms autocorrelation in Ta-Tw regression model residuals but this is seldom acknowledged by other studies. In the River Dove, autocorrelation is manifested by under-estimation of Tw in summer and over-estimation in winter. Accounting for this autocorrelation would improve the explanatory power of Ta-Tw regression models. However, there is no correlation between residuals and our chosen environmental characteristics. Positive autocorrelation (i.e., day to day persistence) occurs in Tw because of the time taken for water to move through the network, incorporating a lag in the response of daily Tw to Ta. Figure 7 shows that downstream sites are affected by autocorrelation to a greater extent than upstream sites and that there is marginally greater explanatory power (for sites D13 to D22) when Ta is lagged by one day (i.e. the reduction in $\mathrm{R}^{2}$ is negative). Local groundwater inputs in the lower Dove disrupt this general finding.

\section{Estimation of logistic model parameters from catchment properties}

Despite high explanatory power, the statistical models are site-specific. However, as the three regression parameters are physically interpretable, their values are potentially predictable from environmental gradients. This form of model has not been attempted before, but previous studies have developed multiple linear regressions to predict weekly and monthly Tw from catchment characteristics. These studies report various factors that are significantly correlated with Tw, including elevation, catchment area, percentage forest cover and hillslope shading (Imholt et al., 2012). In addition, Ozaki et al. (2003) related the slope of linear regressions between daily Ta and Tw in five rivers to catchment area. 
472 Some factors may appear significant due to covariance amongst parameters. For example, the 473 width-to-depth ratio is important in determining the surface area of water over which energy 474 fluxes occur but also increases with distance downstream. In addition, parameters that are significant in one river may not be elsewhere because environmental parameters interact. For example, vegetation cover may be important in the absence of valley shade, but of less significance in rivers that are deeply incised. Shading by vegetation is also likely to be of greater significance to narrow channels in comparison to wide channels. Vegetation patch size, shape, tree density and canopy characteristics could all be used to better characterise riparian shade. Consequently, care needs to be taken in the construction of statistical models and factors need to be incorporated based on plausible, causal relationships with Tw, not based solely on the strength of correlations.

The only significant correlation found for the Dove and Manifold was between the $\gamma$ parameter and cumulative riparian shade. This suggests that shade influences the responsiveness of Tw to Ta on these rivers and, hence, may provide a useful buffer against future increases in Ta. This is consistent with other studies that have found shaded reaches are cooler than un-shaded (Bowler et al., 2012) and experimental studies that show artificial shade can cool river reaches (Johnson, 2004). Broadmeadow et al. (2011) report that shade, measured as the percentage of tree cover in $30 \mathrm{~m}$ buffer strips along the channel edge, was significantly correlated to maximum summer Tw at a range of scales from $100 \mathrm{~m}$ to $1 \mathrm{~km}$, but was not significantly correlated over interannual timescales.

Trees along the Dove and Manifold are broadleaved hence shading will be at a maximum in summer. This is evident in the skill of logistic regression models calibrated on bi-monthly blocks of daily mean Tw: the amount of explained variance falls in May-June, reaches a minimum in July-August, before recovering in September-October (Figure 10). This reflects seasonal emergence, fullest shade and leaf fall, affecting the strength of the Ta-Tw relationship as well as the relative contribution of groundwater sources to overall channel flow. In other words, seasonal variations in canopy shade and groundwater as a percentage of total channel flow are at their greatest in the lower Dove in the summer, hence the amount of variance explained by Ta is lowest at this time.

Strong inter-site correlations indicate that upstream Tw is very similar to that downstream, as would be expected. Lower inter-site correlations between neighbouring sites are associated 
with zones of groundwater influx, especially between sites D22 and D23 (Figure 4). Autocorrelation analysis provides a tool for evaluating local versus catchment controls of water temperature. For example, Tw at site D11 is highly correlated ( $r=0.98)$ with D10, and is separated by $2.2 \mathrm{~km}$. This implies that most of the variability in Tw at site D11 can be explained by that inherited from upstream areas. Consequently, it unsurprising that logistic regression parameters are better correlated with cumulative rather than local shading. However, the result could also be an artefact of covariance amongst variables because, in fluvial systems, many environmental factors have downstream trends related to altitude and morphological gradients. The low explanatory power of regressions between $\alpha, \beta$ and $\gamma$ and distance from source and altitude suggests that this effect is limited in the Dove and Manifold.

\section{Identifying sites that are vulnerable to warming}

518 The homogeneity of $\mathrm{Tw}$ in the Manifold means it is challenging to identify reaches for 519 mitigation and/or creation of thermal refuges. However, given the spatial uniformity in Tw it is arguably the river in greater need of management and refuge creation as increasing Ta could affect the whole river length. On the other hand, the Dove is more heterogeneous and, in the context of increased Tw, could still contain cool water habitats buffered by groundwater. Sites with perennial spring flows (Table 4) are therefore likely to be of high ecological value and should be protected from other pressures, such as cattle poaching and inputs of agricultural pollutants. Even so, rising temperatures at sites between refuges may act as thermal barriers to animal movements and more research is needed on the movement and changing distribution of animals relative to meso-scale thermal features (Torgerson et al., 1999; Ebersole et al., 2003; Stevens and DuPont, 2011). Other work shows that thermal refuges may be created at very local levels - even at habitat scales (e.g., Everall et al., 2012).

Logistic regression modelling reveals sites that are particularly susceptible to change or conducive to management. The $\alpha$-parameter is the upper asymptote of the model and, therefore, indicates the maximum predicted Tw. It is clear that groundwater dominated reaches, such as D23 have much lower asymptotes than mid- and downstream reaches (Table 3). Therefore, sites of low $\alpha$ (high groundwater influx) may provide thermal refuge for organisms in the context of climate change. It is also apparent that, although the Manifold has higher temperatures and a greater Tw range (Figure 8), it has lower $\alpha$ values than the Dove at similar distances from source, indicating that the Dove has the potential to achieve greater maximum Tw than the Manifold (especially in the vicinity of sites D20 to D22). However, 
there is greater uncertainty in estimated extreme values due to the limited data available for model calibration at the tails of the distribution. Confidence in these parameters will be improved by long-term monitoring and evaluation of the statistical models.

As noted before, $\alpha$ and $\beta$ parameters are strongly correlated, but $\gamma$ has little association with the other regression parameters (Mohensi et al., 1998). For example, D18 has the highest $\alpha$ but relatively low $\gamma$ (Figure 5). This suggests that sites that have the potential to reach the highest Tw are not necessarily the most responsive to changes in mid-range Ta. It is possible that $\alpha$ is largely related to water inherited from upstream because this governs the heat capacity of a river. This is supported by the downstream trend in $\alpha$, with lower values at the source of rivers. Variations in the downstream trend in $\alpha$ are associated with groundwater (D17, D23) and tributary inputs (M14), which will also substantially affect the thermal load of the river.

The $\gamma$ parameter reveals sites that are most sensitive to unit warming. The Manifold has the highest $\gamma$ values, indicating that it is more responsive to changes in Ta. Here, a $1^{\circ} \mathrm{C}$ increase in Ta is associated with a $0.82-0.94^{\circ} \mathrm{C}$ rise in Tw at $13^{\circ} \mathrm{C}$ and a $0.24-0.34^{\circ} \mathrm{C}$ rise at $25^{\circ} \mathrm{C}$. All sites in the Dove have lower $\gamma$ than those in the Manifold, especially those at D15, D16, D17 and D23 downstream of springs. Sites most responsive to Ta change are in upstream reaches of both rivers, probably because of the lower thermal inertia. It is further hypothesised that because the Manifold has less vegetation cover and valley shade it is more responsive to Ta than the Dove which has substantial shading in some reaches. This is supported by the significant correlation between $\gamma$ and cumulative tree cover (Figure 9). The heavily wooded reaches in this study have $\gamma$-values $\sim 0.1$ whereas sites in the Manifold that lack shade have $\gamma>0.18$. Vegetation explains $68 \%$ of the variance in $\gamma$ suggesting that loss of shade (perhaps due to Ash die-back) could increase Tw at downstream sites.

\section{CONCLUSIONS}

We distinguish between independent variables included in site-specific regression models and those incorporated within a generalised model to infer logistic regression model parameters. Predictors of Tw, such as Ta (as a surrogate for solar radiation) and water volume should be incorporated into the site-specific models. Alternatively, controls on Tw, such as shading and width-to-depth ratio, which do not heat or cool water but effect how water is heated or cooled, should be included in over-arching models to predict regression parameters. This is because 
the relationship between $\mathrm{Tw}$ and landscape controls is universal in the absence of river management: the warming of a unit volume of water will always be heated by the same degree if the amount of solar radiation is the same and all other factors are constant, including the assumption that other heat sources are negligible (Hannah et al., 2008; Ouellet et al., 2012). The spatial and temporal heterogeneity in Tw is due to the multitude of indirect factors, such as riparian and landscape shading, hydrological pathways, hydrogeology, river morphology and meteorological conditions. It is because of these controls, and uncertainty in parameter estimation, that logistic regression parameters are not identical at all sites along studied rivers.

This paper provides an initial feasibility assessment of generalising models of Tw. Although only cumulative vegetative shade was significantly correlated with regression parameters $(\gamma)$, it is clear that spatial gradients are present in the logistic model parameters. There is also strong evidence that groundwater inputs in the Dove locally alter these parameters. The next step for LUTEN is to incorporate more detailed assessment of hydrological and landscape controls of Tw, including higher resolution shade indices derived from valley geometry relative to the motion of the sun (as in Lee et al., 2012). Year two of monitoring includes periods of exceptionally wet conditions in England, providing an opportunity to test the model under extreme weather and to investigate thermal dynamics during periods of high and

593 low flow. This will also be aided by an expanded network of sites, including the 594 instrumentation of a tributary within the Manifold and more systematic monitoring of springs. Moreover, there is scope for further analysis and mixture modelling, including estimation of daily water temperature ranges, or more sophisticated treatment of autocorrelation and seasonal variations in the model residuals. However, the ultimate goal remains the development of low-cost techniques for estimating vulnerability of river reaches and aquatic habitats to rising temperatures based on readily available catchment information.

\section{ACKNOWLEDGEMENTS}

We thank the land-owners for granting access to the monitoring sites. We are also grateful to the Wild Trout Trust and Trent Rivers Trust for their sponsorship. In addition, we thank Andrew Pledger, Annie Ockelford and Julian O’Neill for field and laboratory assistance. The constructive remarks of two anonymous referees are acknowledged too. 


\section{REFERENCES}

Abesser, C. and Smedley, P.L. 2008. Baseline groundwater chemistry: the Carbonferous Limestone aquifer of the Derbyshire Dome. British Geological Survey Open Report, OR/08/028, Keyworth, 64pp.

Bourque CP-A, Pomeroy JH. 2001. Effects of forest harvesting on summer stream temperatures in New Brunswick, Canada: an inter-catchment, multiple-year comparison. Hydrology and Earth System Sciences 5: 599-613.

Bowler DE, Mant R, Orr H, Hannah DM, Pullin AS. 2012. What are the effects of wooded riparian zones on stream temperature? Environmental Evidence 1: 3.

Brassington, F.C. 2007. A proposed conceptual model for the genesis of the Derbyshire thermal springs. Quarterly Journal of Engineering Geology and Hydrogeology, 40: 35-46.

Briers RA, Gee JHR, Geoghegan R. 2004. Effects of the North Atlantic Oscillation on growth and phenology of stream insects. Ecography 27: 811-817.

Broadmeadow SB, Jones JG, Langford TEL, Shaw PJ, Nisbet TR. 2011. Influence of riparian shade on lowland stream water temperatures in southern England and their viability for brown trout. River Research and Applications 27: 226-237.

Caissie D. 2006. The thermal regime of rivers: a review. Freshwater Biology 51: 1389-1406.

Centre for Ecology and Hydrology (CEH). 2012. An overview of the 2010-12 drought and its dramatic termination. Briefing report. Available at: http://www.ceh.ac.uk/data/nrfa/nhmp/other_reports/2012_Drought_Transformation.pdf [accessed December 2012]

Constantz J. 1998. Interaction between stream temperature, streamflow, and groundwater exchanges in alpine streams. Water Resources Research 34: 1609-1615.

Crisp DT, Howson G. 1982. Effect of mean air temperature upon mean water temperature in streams in the north Pennines and English Lake District. Freshwater Biology 12: 359-367. 
642 Dalton RT, Fox HR. 1988. Channel change on the River Dove. East Midland

643 Geographer 11: 40-47.

644

Durance I, Ormerod SJ. 2007. Climate change effects on upland stream macroinvertebrates over a 25-year period. Global Change Biology 13: 942-957.

648 Ebersole JL, Liss WJ, Frissell CA. 2003. Cold water patches in warm streams: 649 Physicochemical characteristics and the influence of shading. Journal of the American Water Resources Association 39: 355-368.

651

Edmunds, W.M. 1971. Hydrogeochemistry of groundwaters in the Derbyshire Dome with 653 special reference to trace constituents. Report of the Institute of Geological Sciences, 71/7, British Geological Survey, Keyworth.

655

Elliott JM, Elliott JA. 1995. The critical thermal limits for the bullhead, Cottus gobio, from three populations in north-west England. Freshwater Biology 33: 411-418.

Environment Agency. 2012. Keeping Rivers Cool: Getting ready for climate change by 660 creating riparian shade. Environment Agency, Bristol, UK.

661

662

Everall NC, Farmer A, Heath AF, Jacklin TE, Wilby RL. 2012. Ecological benefits of 663 creating messy rivers. Area 44: 470-478.

664

Gunn, J., Bottrell, S.H., Lowe, D.J. and Worthington, S.R.H. 2006. Deep groundwater flow 666 and geochemical processes in limestone aquifers: evidence from thermal waters in 667 Derbyshire, England, UK. Hydrogeology Journal, 14: 868-881.

Hannah DM, Malcolm IA, Soulsby C, Youngson AF. 2008. A comparison of forest and 
673 Hrachowitz M, Soulsby C, Imholt C, Malcolm IA, Tetzlaff D. 2010. Thermal regimes in a 674 large upland salmon river: a simple model to identify the influence of landscape controls and

675

676

677

678

679

680

681

682

683

684

685

686

687

688

689

690

691

692

693

694

695

696

697

698

699

700

701

702

703

704

Hari RE, Livingstone DM, Siber R, Burkhardt-Holm P, Güttinger H. 2006. Consequences of climatic change for water temperature and brown trout populations in Alpine rivers and streams. Global Change Biology 12: 10-26.

Hulme M, Jenkins GJ, Lu X, Turnpenny JR, Mitchell TD, Jones RG, Lowe J, Murphy JM, Hassell D, Boorman P, McDonald R, Hill S. 2002. Climate Change Scenarios for the United Kingdom: The UKCIP02 Scientific Report. Tyndall Centre for Climate Change Research, School of Environmental Sciences, University of East Anglia, Norwich, UK.

Imholt C, Soulsby C, Malcolm IA, Hrachowitz M, Gibbins CN, Langan S, Tetzlaff D. 2012. Influence of scale on thermal characteristics in a large montane river basin. River Research and Applications. Early view. DOI: 10.1002/rra.1608.

Johnson MF and Wilby RL. 2013a. Shield or not to shield: Testing water temperature sensor deployment under laboratory conditions. Water, in preparation.

Johnson MF and Wilby RL. 2013b. Quantifying landscape and riparian shade effects on river water temperature. Hydrology and Earth System Sciences, in preparation.

Johnson SL. 2003. Stream temperature: scaling of observations and issues for modelling. Hydrological Processes 17: 497-499.

Johnson SL. 2004. Factors influencing stream temperatures in small streams: substrate effects and a shading experiment. Canadian Journal of Fisheries and Aquatic Science 61: 913-923.

Jonsson B, Forseth T, Jensen AJ, Naesje TF. 2001. Thermal performance of juvenile Atlantic salmon, Salmo salar L. Functional Ecology 15: 701-711. 
Kaushal SS, Likens GE, Jaworski NA, Pace ML, Sides AM, Seekell D, Belt KT, Secor DH, Wingate RL. 2010. Rising stream and river temperatures in the United States. Frontiers in Ecology and the Environment 8: 461-466.

Lee TY, Huang JC, Kao SJ, Liao LY, Tzeng CS, Yang CH, Kalita PK, Tung CP 2012. Modeling the effects of riparian planting strategies on stream temperature: Increasing suitable habitat for endangered Formosan Landlocked Salmon in Shei-Pa National Park, Taiwan. Hydrological Processes 26: 3635-3644.

Lewis TE, Lamphear DW, McCanne DR, Webb AS, Krieter JP, Conroy WD. 2000. Regional assessment of stream temperatures across northern California and their relationship to various landscape-level and site-specific attributes. Forest Science Project. Humboldt State University Foundation, Arcata, CA.

Li, HW, Lamberti GA, Pearsons TN, Tait CK, Li JL, Buckhouse JC. 1994. Cumulative effects of riparian disturbances along high desert trout streams of the John Day Basin, Oregon. Transactions of the American Fisheries Society 123: 627-640.

Mackey AP, Berrie AD. 1991. The prediction of water temperature in chalh streams from air temperatures. Hydrobiologia 210: 183-189.

Malcolm IA, Soulsby C, Hannah DM, Bacon PJ, Youngson AF, Tetzlaff D. 2008. The influence of riparian woodland on stream temperatures: implications for the performance of juvenile salmonids. Hydrological Processes 22: 968-979.

Mohensi O, Erickson TR, Stefan HG. 2002. Upper bounds for stream temperatures in the contiguous United States. Journal of Environmental Engineering 128: 4-11.

Mohensi O, Stefan HG, Erickson TR. 1998. A nonlinear regression model for weekly stream temperatures. Water Resources Research 34: 2685-2692.

Moore RD, Spittlehouse DL, Story A. 2005. Riparian microclimate and stream temperature esponse to forest harvesting: a review. Journal of the American Water Resources Association 41: 813-834. 
740 Naiman RJ, Beechie TJ, Benda LE, Berg DR, Bisson, MacDonald LH, O’Connor MD, Olsen 741 PL, Steel EA. 1992. Fundamental elements of ecologically healthy watersheds in the Pacific 742 Northwest coastal ecoregion. In: Naiman RJ. (ed) Watershed management: Balancing 743 sustainability and environmental change. Springer-Verlag, New York. pp. 127-188.

745 Neilson, B.T., Stevens, D.K., Chapra, S.C. and Bandaragoda, C. 2009. Data collection methodology for dynamic temperature model testing and corroboration. Hydrological Processes, 23: 2902-2914.

O’Driscoll MA, DeWalle DR. 2006. Stream-air temperature relations to classify streamground water interactions in a karst setting, central Pennsylvania, USA. Journal of Hydrology 329: $140-153$.

Ouellet V, Secretan Y, St-Hilaire A, Morin J. 2012. Water temperature modelling in a controlled environment: comparative study of heat budget equations. Hydrological Processes, early view DOI: 10.1002/hyp.9571

Ozaki N, Fukushima T, Harasawa H, Kojiri T, Kawashima K, Ono M. 2003. Statistical analyses on the effects of air temperature fluctuations on river water qualities. Hydrological Processes 17: 2837-2853.

Poole GC, Berman CH. 2001. An ecological perspective on in-stream temperature: natural heat dynamics and mechanisms of human-caused thermal degradation. Environmental Management 27: 787-802.

Rice, S. and Toone, J.A. 2010. Fluvial audit of the Upper Dove Catchment, Derbyshire and Staffordshire, UK. Natural England Survey Report.

Rutherford JC, Marsh NA, Davies PM, Bunn SE. 2004. Effects of patchy shade on stream water temperature: how quickly do small streams heat and cool? Marine and Freshwater 
Sowder, C. and Steel, E.A. 2012. A note on the collection and cleaning of water temperature data. Water, 4: 597-606.

Stefan HG, Preud'homme EB. 1993. Stream temperature estimation from air temperature. Water Resource Research 29: 27-45.

Stevens BS, DuPont JM. 2011. Summer use of side-channel thermal refugia by salmonids in the North Fork Coeur d'Alene River, Idaho. North American Journal of Fisheries Management 31: 683-692.

Story A, Moore RD, Macdonald JS. 2003. Stream temperatures in two shaded reaches below cutblocks and logging roads: downstream cooling linked to subsurface hydrology. Canadian Journal of Forest Research 33: 1383-1396.

Toone JA, Wilby RL, Rice S. 2011. Surface-water temperature variations and river corridor properties. Water Quality: Current Trends and Expected Climate Change Impacts Proceedings of symposium H04 held during IUGG2011 in Melbourne, Australia, July 2011. IAHS Publication 348; 129-134.

Torgersen CE, Faux RN, McIntosh BA, Poage NJ, Norton DJ. 2001. Airborne thermal remote sensing for water temperature assessment in rivers and streams. Remote Sensing of Environments 76: 386-398.

Torgersen CE, Price DM, Li HW, McIntosh BA. 1999. Multiscale thermal refugia and stream habitat associations of Chinook salmon in northeastern Oregon. Ecological Applications 9: 301-319.

van Vleit MTH, Ludwig F, Zwolsman JJG, Weedon GP, Kabat P. 2011. Global river temperatures and sensitivity to atmospheric warming and changes in river flow. Water Resources Research 47: W02544, doi:10.1029/2010WR009198

Webb BW, Hannah DM, Moore RD, Brown LE, Nobilis F. 2008. Recent advances in stream and river temperature research. Hydrological Processes 22: 902-918. 
Webb BW, Nobilis F. 1997. A long-term perspective on the nature of the airwater temperature relationship: a case study. Hydrological Processes 11: 137-147.

Webb BW, Walling DE. 1985. Temporal variation of river water temperature in a Devon river system. Hydrological Science Journal-Journal des Science Hydrologique 30: 449-464.

Webb BW, Walling DE. 1986. Spatial variation of water temperature characteristics and behaviour in a Devon river system. Freshwater Biology 16: 585-608.

Webb BW, Walling DE. 1997. Complex summer water temperature behaviour below a UK regulating reservoir. Regulated Rivers: Research \& Management 13: 463-477.

Webb BW, Walsh AJ. 2004. Changing UK river temperatures and their impact on fish populations. Hydrology: science and practice for the $21^{\text {st }}$ century, Volume II. Proceedings of the British Hydrological Society International Conference, Imperial College, London, July 2004; 177-191.

Webb BW, Zhang Y. 1997. Spatial and seasonal variability in the components of the river heat budget. Hydrological Processes 11: 79-101.

Webb BW, Zhang Y. 1999. Water temperatures and heat budgets in Dorset Chalk water courses. Hydrological Processes 13: 309-321.

Wehrly KE, Wang L, Mitro M. 2007. Field-based estimates of thermal tolerance limits for trout: incorporating exposure time and temperature fluctuation. Transactions of the American Fisheries Society 136: 365-374.

Wilby RL, Johnson MF, Toone JA. 2012. The Loughborough University TEmperature Network (LUTEN): Rationale and analysis of stream temperature variations. Proceedings of Earth Systems Engineering 2012: Systems Engineering for Sustainable Adaptation to Global Change. Newcastle, UK.

Yonus M, Hondzo M, Engel BA. 2000. Stream temperature dynamics in upland agricultural watersheds. Journal of Environmental Engineering 126: 518-526. 
840

841 Zwieniecki MA, Newton M. 1999. Influence of streamside cover and stream features on 842 temperature trends in forested streams of western Oregon. Western Journal of Applied 843 Forestry 14:106-113.

844 
845 Table 1: Reach descriptors, annual daily mean and maximum Ta, Tw, and mean conductivity, for monitoring sites on the Rivers Dove and

846 Manifold with more than 90\% complete records. Temperature and conductivity statistics are for the period 1 March 2011 to 29 February 2012.

\begin{tabular}{|c|c|c|c|c|c|c|c|c|c|c|c|c|c|c|c|c|}
\hline \multirow[b]{2}{*}{ Site } & \multirow{2}{*}{$\begin{array}{c}\text { Distance } \\
\text { (km) }\end{array}$} & \multirow{2}{*}{$\begin{array}{l}\text { Altitude } \\
\text { (m) }\end{array}$} & \multirow[b]{2}{*}{ Slope } & \multirow[b]{2}{*}{ Sinuosity } & \multirow{2}{*}{$\begin{array}{l}\text { Upstream } \\
\text { weirs }\end{array}$} & \multirow{2}{*}{$\begin{array}{c}\text { Upstream } \\
\text { catchment } \\
\left(\mathbf{k m}^{2}\right)\end{array}$} & \multicolumn{2}{|c|}{ Bank full (m) } & \multirow{2}{*}{$\begin{array}{l}\text { Cond. } \\
\left(\mu \mathrm{s}^{-1}\right)\end{array}$} & \multicolumn{2}{|c|}{ Topographic shade } & \multirow{2}{*}{$\begin{array}{l}\text { Riparian } \\
\text { cover (\%) }\end{array}$} & \multicolumn{4}{|c|}{ Temperature $\left({ }^{\circ} \mathrm{C}\right)$} \\
\hline & & & & & & & Width & Depth & & $\begin{array}{l}\% \text { time } \\
\text { shaded }\end{array}$ & $\begin{array}{c}\% \text { total } \\
\text { irradiance* }\end{array}$ & & $\begin{array}{c}\text { Ta- } \\
\text { Mean }\end{array}$ & $\begin{array}{c}\text { Tw- } \\
\text { Mean }\end{array}$ & $\begin{array}{c}\text { Ta- } \\
\text { Max } \\
\end{array}$ & $\begin{array}{l}\text { Tw- } \\
\text { Max } \\
\end{array}$ \\
\hline D2 & 1.8 & 348 & 0.055 & 1.15 & 0 & 3.5 & 1.7 & 0.4 & 211 & 52 & 74 & 36 & 8.4 & 8.7 & 12.6 & 10.0 \\
\hline D3 & 2.8 & 308 & 0.040 & 1.12 & 0 & 9.6 & 4.1 & 0.6 & 166 & 42 & 83 & 90 & 9.0 & 8.9 & 13.2 & 10.1 \\
\hline D4 & 4.1 & 283 & 0.018 & 1.37 & 0 & 11.1 & 4.7 & 0.7 & 150 & 35 & 88 & 88 & 8.4 & 8.7 & 12.1 & 9.9 \\
\hline D9 & 7.7 & 254 & 0.008 & 1.56 & 1 & 25.3 & 5.3 & 1.2 & 197 & 7 & 99 & 86 & 8.7 & 9.4 & 12.4 & 10.5 \\
\hline D10 & 9.6 & 244 & 0.006 & 1.37 & 3 & 30.5 & 6.2 & 1.3 & 222 & 21 & 95 & 82 & 8.7 & 9.5 & 13.1 & 10.5 \\
\hline D11 & 11.8 & 230 & 0.005 & 1.22 & 3 & 34.4 & 6.2 & 1.5 & 269 & 22 & 95 & 34 & 9.0 & 9.8 & 13.3 & 10.8 \\
\hline D12 & 13.0 & 230 & 0.005 & 1.29 & 3 & 35.7 & 7.6 & 1.2 & 286 & 16 & 97 & 69 & 8.7 & 9.7 & 13.2 & 10.9 \\
\hline D13 & 14.3 & 227 & 0.001 & 1.25 & 3 & 39.1 & 5.4 & 0.6 & 336 & 16 & 97 & 48 & 9.0 & 10.0 & 13.0 & 11.5 \\
\hline D15 & 18.1 & 214 & 0.003 & 1.48 & 5 & 74.4 & 6.4 & 1.7 & 299 & 10 & 98 & 7 & 9.1 & 9.9 & 14.0 & 10.9 \\
\hline D16 & 19.0 & 214 & 0.001 & 1.48 & 8 & 75.1 & 8.6 & 1.0 & 404 & 8 & 99 & 0 & 9.1 & 9.9 & 14.1 & 10.7 \\
\hline D17 & 20.9 & 213 & 0.001 & 1.88 & 16 & 79.8 & 5.7 & 0.8 & 401 & 55 & 76 & 9 & 8.3 & 9.9 & 12.4 & 10.5 \\
\hline D18 & 22.5 & 205 & 0.001 & 1.33 & 29 & 86.9 & 10.1 & 0.9 & 498 & 51 & 76 & 29 & 8.8 & 9.8 & 13.2 & 10.8 \\
\hline D20 & 25.8 & 180 & 0.001 & 1.22 & 80 & 109.0 & 11.3 & 0.8 & 356 & 45 & 85 & 18 & 9.4 & 10.8 & 13.6 & 11.8 \\
\hline D21 & 27.6 & 163 & 0.001 & 1.52 & 95 & 125.0 & 11.7 & 0.7 & 355 & 55 & 73 & 11 & 9.3 & 10.6 & 13.0 & 11.5 \\
\hline D22 & 27.8 & 163 & 0.000 & 1.34 & 96 & 125.1 & 9.7 & 1.0 & 355 & 38 & 89 & 40 & 9.4 & 10.6 & 13.6 & 11.4 \\
\hline D23 & 29.3 & 153 & 0.001 & 1.26 & 107 & 131.0 & 11.6 & 1.5 & 501 & 55 & 72 & 38 & 8.6 & 9.1 & 12.5 & 9.8 \\
\hline M2 & 3.6 & 334 & 0.032 & 1.70 & 0 & 3.0 & 2.9 & 0.6 & 439 & 28 & 94 & 8 & 8.9 & 8.9 & 15.8 & 10.5 \\
\hline M3 & 3.9 & 329 & 0.015 & 1.28 & 0 & 9.0 & 8.3 & 0.6 & 532 & 25 & 93 & 0 & 8.9 & 9.2 & 13.5 & 11.0 \\
\hline M6 & 6.6 & 288 & 0.018 & 1.15 & 0 & 10.5 & 5.1 & 1.2 & 212 & 21 & 95 & 91 & 8.4 & 9.1 & 12.5 & 10.7 \\
\hline M8 & 8.2 & 269 & 0.014 & 1.17 & 0 & 11.0 & 7.0 & 0.8 & 206 & 7 & 100 & 55 & 8.3 & 9.3 & 12.4 & 11.0 \\
\hline M9 & 10.6 & 250 & 0.008 & 1.26 & 0 & 12.7 & 6.3 & 1.1 & 208 & 5 & 100 & 77 & 9.0 & 9.6 & 12.8 & 10.8 \\
\hline M12 & 13.6 & 228 & 0.005 & 1.67 & 0 & 33.9 & 8.1 & 1.1 & 193 & 0 & 100 & 53 & 8.8 & 9.6 & 14.1 & 11.0 \\
\hline M14 & 15.2 & 224 & 0.000 & 1.39 & 0 & 38.6 & 5.7 & 1.2 & 242 & 11 & 98 & 10 & 9.2 & 10.2 & 14.6 & 11.4 \\
\hline M15 & 16.2 & 219 & 0.006 & 1.25 & 1 & 73.9 & 7.3 & 0.8 & 193 & 0 & 100 & 22 & 8.9 & 9.7 & 12.9 & 10.8 \\
\hline M16 & 18.3 & 209 & 0.004 & 1.62 & 2 & 74.6 & 8.5 & 1.4 & 211 & 34 & 89 & 31 & 8.9 & 9.9 & 13.4 & 11.2 \\
\hline
\end{tabular}


848 Table 2: Amount of explained variance $\left(\mathrm{R}^{2}\right)$ in daily mean and maximum Tw by linear and 849 logistic regression models using Ta as the independent variable. The best models are shown 850 in bold. Note that these results are based on site specific Ta.

851

\begin{tabular}{|c|c|c|c|c|}
\hline \multirow{2}{*}{ Site } & \multicolumn{2}{|c|}{ Linear } & \multicolumn{2}{c|}{ Logistic } \\
\cline { 2 - 5 } & Mean & Max & Mean & Max \\
\hline D2 & 0.87 & 0.80 & $\mathbf{0 . 8 8}$ & 0.82 \\
D3 & 0.91 & 0.88 & $\mathbf{0 . 9 1}$ & 0.90 \\
D4 & 0.92 & 0.90 & $\mathbf{0 . 9 3}$ & 0.91 \\
D9 & 0.92 & 0.88 & $\mathbf{0 . 9 3}$ & 0.90 \\
D10 & 0.92 & 0.92 & $\mathbf{0 . 9 3}$ & 0.93 \\
D11 & 0.89 & 0.90 & 0.91 & $\mathbf{0 . 9 2}$ \\
D12 & 0.87 & 0.86 & $\mathbf{0 . 8 9}$ & 0.88 \\
D13 & 0.87 & 0.85 & $\mathbf{0 . 8 9}$ & 0.87 \\
D15 & 0.87 & 0.88 & $\mathbf{0 . 9 0}$ & 0.89 \\
D16 & 0.85 & 0.87 & 0.88 & $\mathbf{0 . 8 8}$ \\
D17 & 0.83 & 0.80 & $\mathbf{0 . 8 6}$ & 0.81 \\
D18 & 0.81 & 0.78 & $\mathbf{0 . 8 4}$ & 0.80 \\
D20 & 0.84 & 0.86 & 0.87 & $\mathbf{0 . 8 8}$ \\
D21 & 0.85 & 0.85 & 0.87 & $\mathbf{0 . 8 7}$ \\
D22 & 0.84 & 0.78 & $\mathbf{0 . 8 6}$ & 0.81 \\
D23 & 0.86 & 0.84 & $\mathbf{0 . 8 7}$ & 0.86 \\
\hline M2 & 0.92 & 0.89 & $\mathbf{0 . 9 3}$ & 0.89 \\
M3 & 0.91 & 0.88 & $\mathbf{0 . 9 2}$ & 0.90 \\
M6 & 0.91 & 0.91 & $\mathbf{0 . 9 3}$ & 0.92 \\
M8 & 0.91 & 0.93 & 0.92 & $\mathbf{0 . 9 4}$ \\
M9 & 0.90 & 0.90 & 0.91 & $\mathbf{0 . 9 2}$ \\
M12 & 0.89 & 0.84 & $\mathbf{0 . 9 0}$ & 0.88 \\
M14 & 0.88 & 0.85 & $\mathbf{0 . 8 9}$ & 0.86 \\
M15 & 0.87 & 0.86 & 0.88 & $\mathbf{0 . 8 9}$ \\
M16 & 0.88 & 0.89 & 0.90 & $\mathbf{0 . 9 1}$ \\
\hline
\end{tabular}


854 Table 3: Logistic regression model parameters $(\alpha, \beta, \gamma)$ with explained variance $\left(\mathrm{R}^{2}\right)$ for 855 calibration (1 March 2011 to 29 February 2012) and validation (1 March 2012 to 31 October 856 2012) periods. Four sites have insufficient data because of sensor loss during high flows in 857 summer/autumn 2012. Note that these results are based on Ta measured at two representative 858 sites (D10 for the Dove, and M8 for the Manifold).

859

\begin{tabular}{|c|c|c|c|c|c|c|c|c|c|}
\hline \multirow[t]{2}{*}{ Site } & \multicolumn{6}{|c|}{ Calibration } & \multicolumn{3}{|c|}{ Validation } \\
\hline & $\begin{array}{c}\alpha \\
\text { asymptote }\end{array}$ & $\begin{array}{c}\beta \\
\text { inflection }\end{array}$ & $\begin{array}{c}\gamma \\
\text { gradient }\end{array}$ & $\begin{array}{l}\mathrm{SE} \\
\left({ }^{\circ} \mathrm{C}\right)\end{array}$ & $\mathbf{R}^{2}$ & $n$ days & $\begin{array}{l}\text { SE } \\
\left({ }^{\circ} \mathbf{C}\right)\end{array}$ & $\mathbf{R}^{2}$ & $n$ days \\
\hline D2 & 16.31 & 10.36 & 0.14 & 1.3 & 0.87 & 329 & 1.0 & 0.67 & 68 \\
\hline D3 & 16.73 & 10.47 & 0.15 & 1.0 & 0.92 & 354 & 1.0 & 0.76 & 70 \\
\hline D4 & 17.66 & 11.07 & 0.14 & 1.0 & 0.94 & 363 & 1.4 & 0.89 & 172 \\
\hline D9 & 19.14 & 11.13 & 0.16 & 1.1 & 0.93 & 348 & 1.2 & 0.86 & 88 \\
\hline D10 & 19.68 & 12.04 & 0.14 & 1.0 & 0.93 & 348 & 1.1 & 0.84 & 202 \\
\hline D11 & 21.93 & 13.43 & 0.11 & 1.0 & 0.93 & 348 & 1.7 & 0.82 & 201 \\
\hline D12 & 23.57 & 14.52 & 0.11 & 1.3 & 0.92 & 362 & 1.6 & 0.84 & 202 \\
\hline D13 & 23.69 & 14.18 & 0.12 & 1.4 & 0.90 & 343 & 1.9 & 0.86 & 181 \\
\hline D15 & 24.58 & 15.85 & 0.10 & 1.2 & 0.91 & 321 & 2.4 & 0.85 & 121 \\
\hline D16 & 23.45 & 15.04 & 0.10 & 1.2 & 0.90 & 361 & 1.9 & 0.80 & 146 \\
\hline D17 & 24.97 & 16.39 & 0.10 & 1.5 & 0.87 & 348 & 1.5 & 0.78 & 112 \\
\hline D18 & 29.61 & 18.25 & 0.10 & 1.8 & 0.87 & 339 & \multicolumn{3}{|c|}{ Insufficient data } \\
\hline D20 & 25.53 & 15.05 & 0.12 & 1.5 & 0.90 & 329 & 2.3 & 0.84 & 167 \\
\hline D21 & 23.69 & 14.18 & 0.12 & 1.4 & 0.90 & 335 & 1.9 & 0.78 & 106 \\
\hline D22 & 23.87 & 14.33 & 0.12 & 1.8 & 0.90 & 337 & 2.1 & 0.79 & 165 \\
\hline D23 & 14.24 & 5.17 & 0.11 & 0.8 & 0.88 & 361 & 1.1 & 0.76 & 104 \\
\hline M2 & 18.06 & 11.06 & 0.19 & 1.1 & 0.93 & 333 & 1.8 & 0.77 & 123 \\
\hline M3 & 19.95 & 11.84 & 0.18 & 1.2 & 0.92 & 332 & 2.2 & 0.60 & 72 \\
\hline M6 & 20.88 & 12.18 & 0.17 & 1.2 & 0.93 & 359 & \multicolumn{3}{|c|}{ Insufficient data } \\
\hline M8 & 22.36 & 12.67 & 0.16 & 1.1 & 0.94 & 366 & 1.4 & 0.90 & 123 \\
\hline M9 & 19.21 & 10.96 & 0.17 & 1.0 & 0.94 & 332 & \multicolumn{3}{|c|}{ Insufficient data } \\
\hline M12 & 20.52 & 11.63 & 0.17 & 1.3 & 0.92 & 354 & 2.4 & 0.74 & 112 \\
\hline M14 & 19.79 & 11.20 & 0.18 & 1.4 & 0.90 & 366 & 2.1 & 0.72 & 123 \\
\hline M15 & 20.03 & 11.45 & 0.18 & 1.4 & 0.90 & 354 & \multicolumn{3}{|c|}{ Insufficient data } \\
\hline M16 & 21.39 & 12.05 & 0.18 & 1.5 & 0.91 & 356 & 2.3 & 0.72 & 119 \\
\hline
\end{tabular}

860 
862 Table 4: An inventory of ephemeral (E) and perennial (P) springs discharging into the River

863 Dove, showing distance downstream, spot conductivity, temperature and pH. See Fig. 3 for a 864 longitudinal survey of spring and main channel temperatures between sites S12 and S21.

865

\begin{tabular}{|c|l|c|c|c|c|c|c|}
\hline Site & Name & $\begin{array}{c}\text { Grid reference } \\
(\mathbf{O S})\end{array}$ & $\begin{array}{c}\text { Distance } \\
(\mathbf{k m})\end{array}$ & $\begin{array}{c}\text { Conductivity } \\
(\boldsymbol{\mu S})\end{array}$ & $\begin{array}{c}\text { Temperature } \\
\left({ }^{\circ} \mathbf{C}\right)\end{array}$ & $\mathbf{p H}$ & Type \\
\hline S1 & Dowell & SK 40755 36755 & 6.2 & 612 & 8.8 & 7.9 & E \\
S2 & Glutton & SK 40845 36650 & 7.2 & 627 & 9.2 & 7.8 & E \\
S3 & Underhill & SK 40875 36645 & 7.8 & 660 & 9.2 & 7.8 & E \\
S4 & Crowdecote & SK 40995 36530 & 10.0 & 598 & 9.0 & 8.0 & E \\
S5 & Cow funnel & SK 41090 36440 & 12.0 & 607 & 10.0 & 7.6 & E \\
S6 & Ludwell & SK 41230 36255 & 15.0 & 645 & 9.4 & 7.8 & E \\
S7 & Sprink & SK 41260 36195 & 15.7 & 622 & 9.2 & 7.8 & E \\
S8 & Hartington & SK 41240 36045 & 18.1 & 717 & 8.7 & $7 / 9$ & E \\
S9 & Beresford & SK 41275 35860 & 21.4 & 666 & 14.2 & 8.4 & E \\
S10 & Wolfescote & SK 41305 35845 & 21.8 & 703 & 9.4 & 8.3 & E \\
\hline S11 & Second gate & SK 41410 35435 & 27.8 & 600 & 7.2 & 7.9 & P \\
S12 & Tar Pit & SK 41405 35415 & 28.0 & 597 & 9.0 & 7.8 & P \\
S13 & Meadow & SK 41405 35410 & 28.1 & 638 & 9.5 & 7.8 & P \\
S14 & Yellow pipe & SK 41410 35405 & 28.1 & 660 & 8.5 & 7.8 & P \\
S15a & Scree slope A & SK 41415 35395 & 28.2 & 675 & 8.9 & 7.9 & P \\
S15b & Scree slope B & SK 41415 35395 & 28.2 & 677 & 8.9 & 7.7 & P \\
S15c & Scree slope C & SK 41415 35395 & 28.2 & 638 & 9.2 & 7.7 & P \\
S16 & Fallen Tree & SK 41420 35390 & 28.3 & 712 & 8.0 & 7.7 & P \\
S17 & Stump & SK 41425 35380 & 28.4 & 703 & 8.1 & 7.7 & P \\
S18 & Big Drop (Nabs) & SK 41430 35375 & 28.5 & 659 & 8.9 & 7.7 & P \\
S19 & Cave & SK 41440 35275 & 29.8 & 600 & 9.2 & 7.7 & P \\
S20 & Underpath & SK 41445 35270 & 29.9 & 717 & 8.4 & 7.7 & P \\
S21 & NT gate & SK 41445 35265 & 29.9 & 661 & 9.3 & 7.7 & P \\
\hline
\end{tabular}

866 
Figure 1: River Dove and Manifold catchments, including temperature monitoring sites (red circles), Environment Agency discharge gauging stations (black circles) and ecological monitoring points (green circles). The grey line marks the boundary between siltstone/ mudstone areas and the Carboniferous limestone outcrop.

872

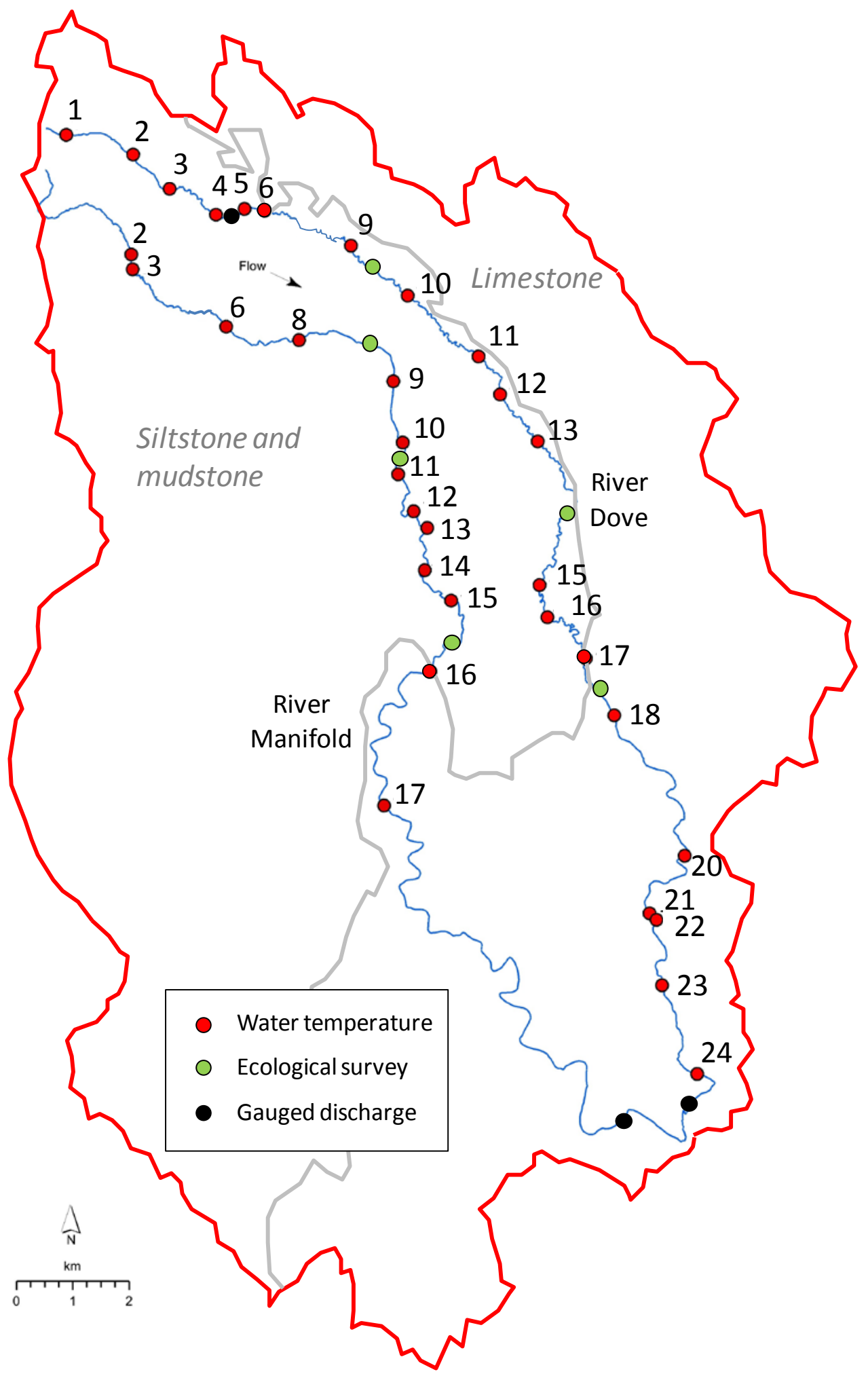


Figure 2: Examples of different categories of riparian shade in the Rivers Dove and Manifold.

a) None
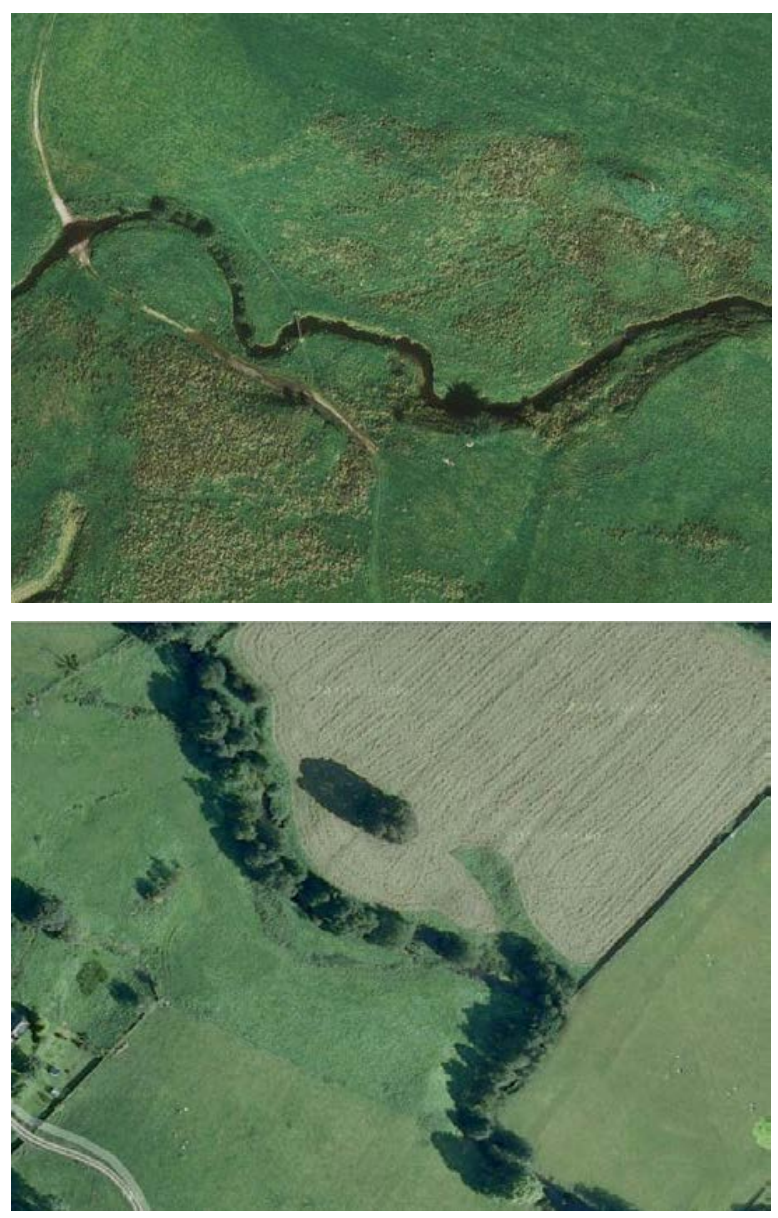

c) Linear b) Patchy
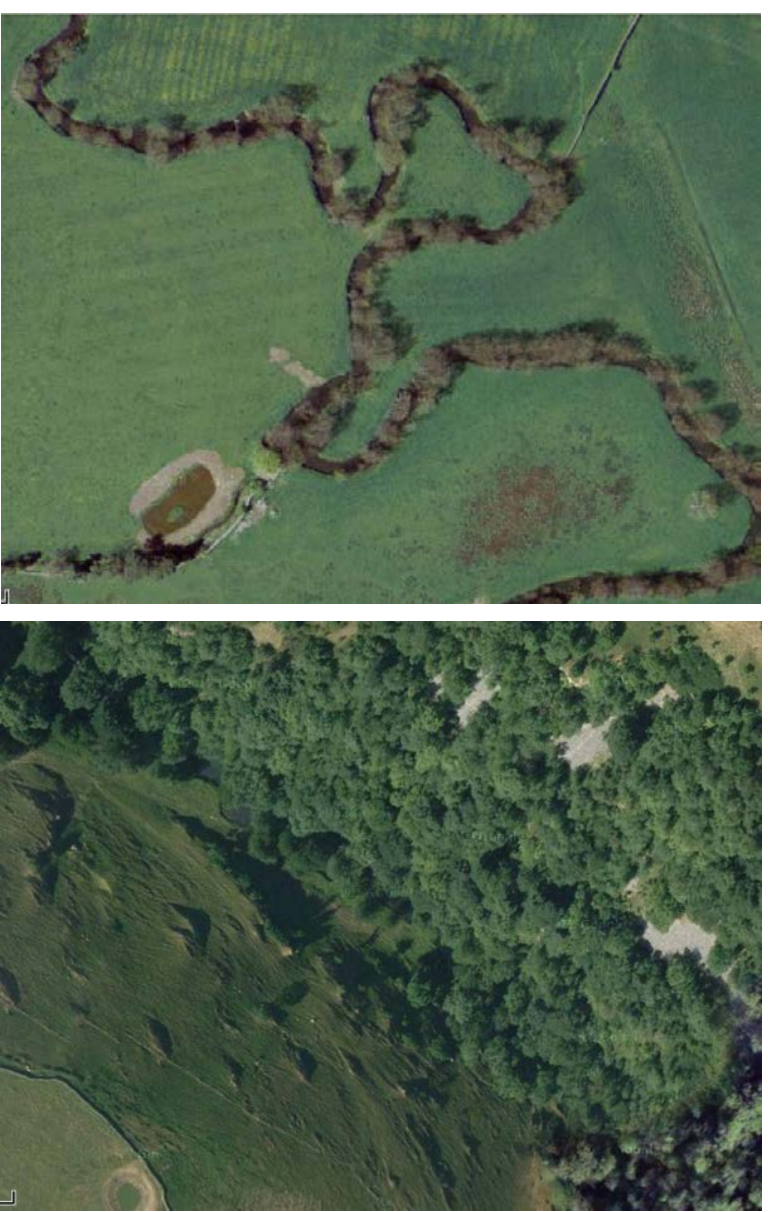

d) Complete 
878 Figure 3: A longitudinal survey of main channel water temperature (upper panel) and 879 conductivity (lower panel) for the River Dove, on 17 ${ }^{\text {th }}$ August 2012 compared with inflows 880 from surface spring heads (S12 to S21, Table 4) downstream of Milldale (D21 in Figure 1).

881
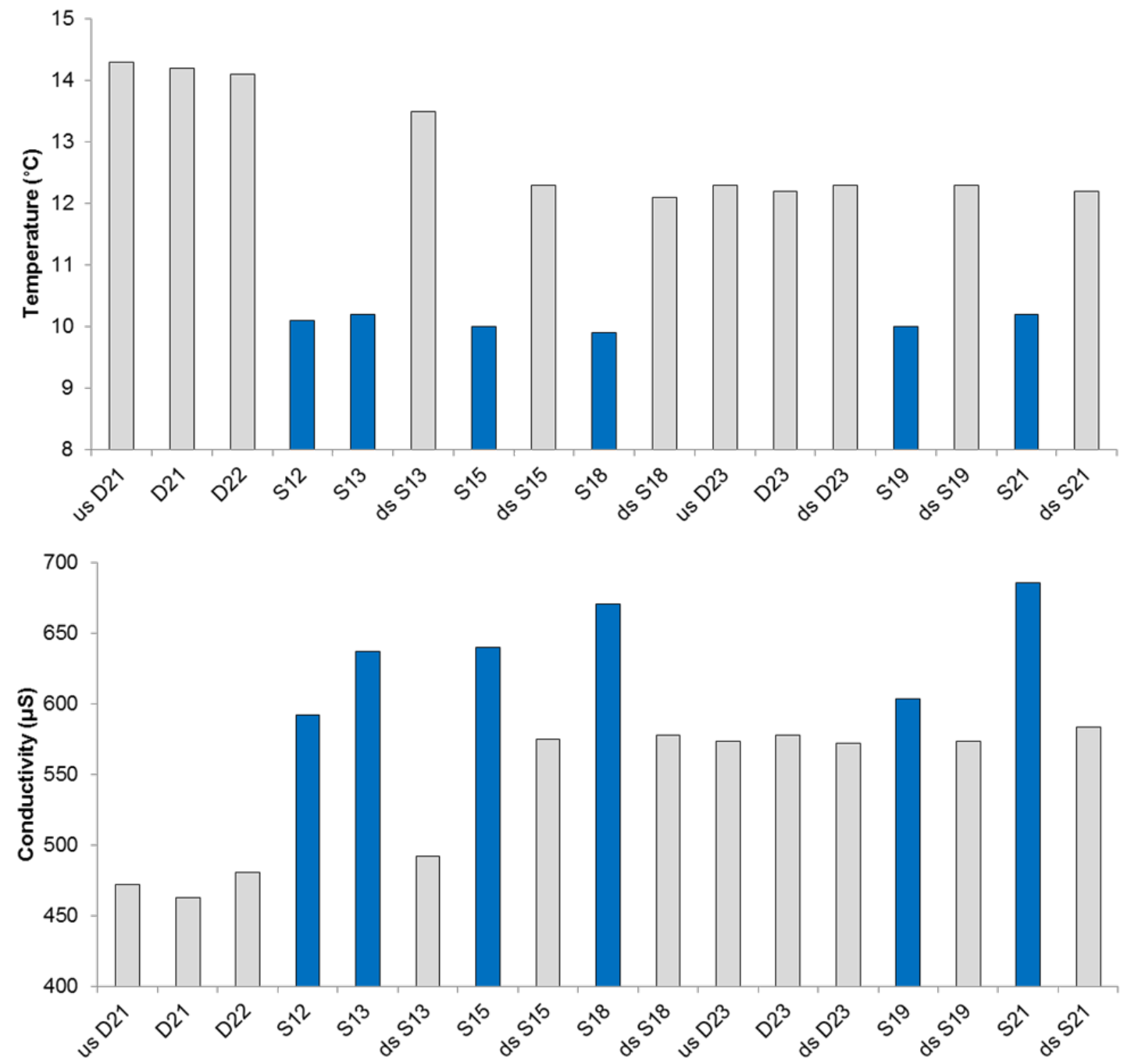
885 Figure 4: Inter-site correlations for daily-maximum Ta (top row) and Tw (bottom row) in the 886 River Dove (left column) and Manifold (right column). Open circles show correlations 887 between Tw at D23 (Dovedale) and all upstream sites.

888

Dove
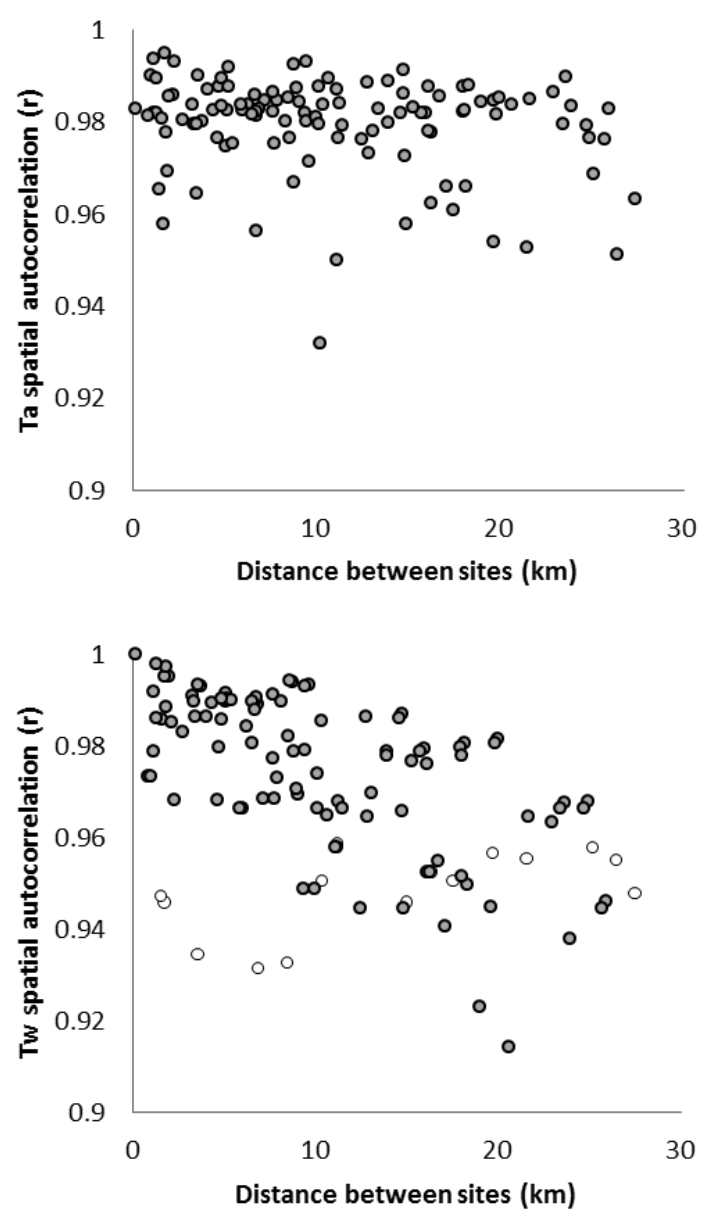

Manifold
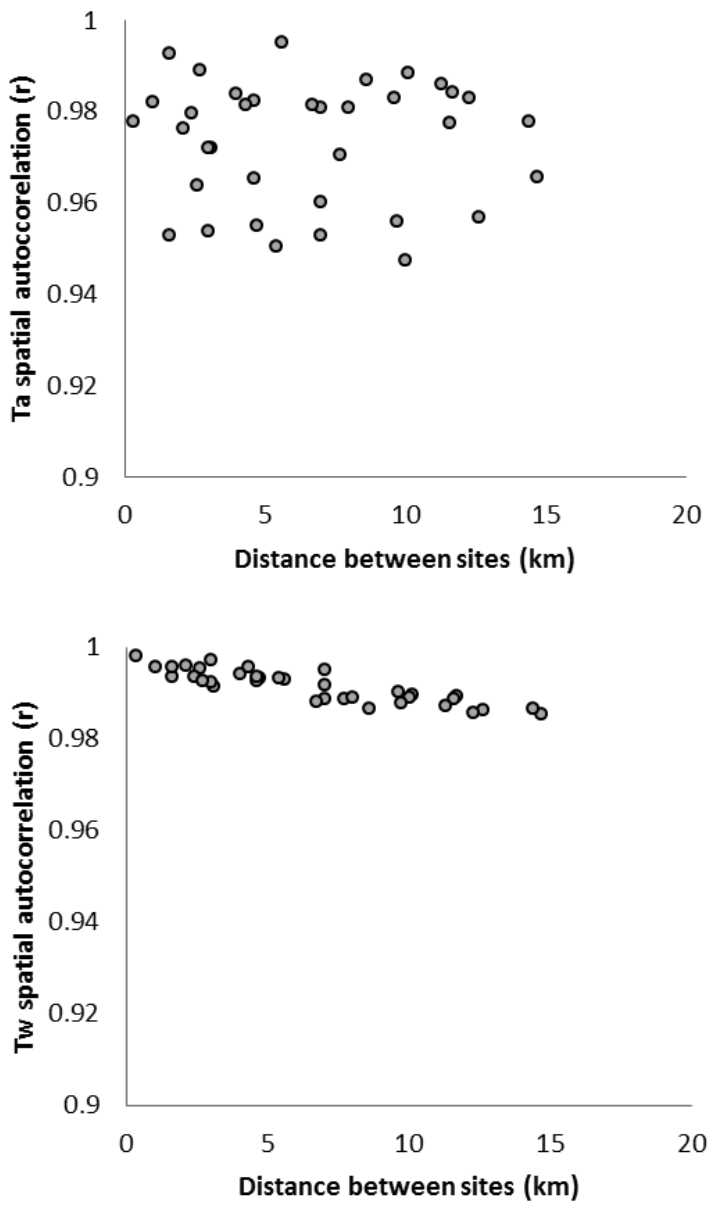

889 
$891 \quad$ Figure 5: Logistic regression models for D2, D10, D18 and D23 showing local $\alpha$ - (horizontal 892 dashed line) and $\beta$-parameters (vertical dashed line).

893
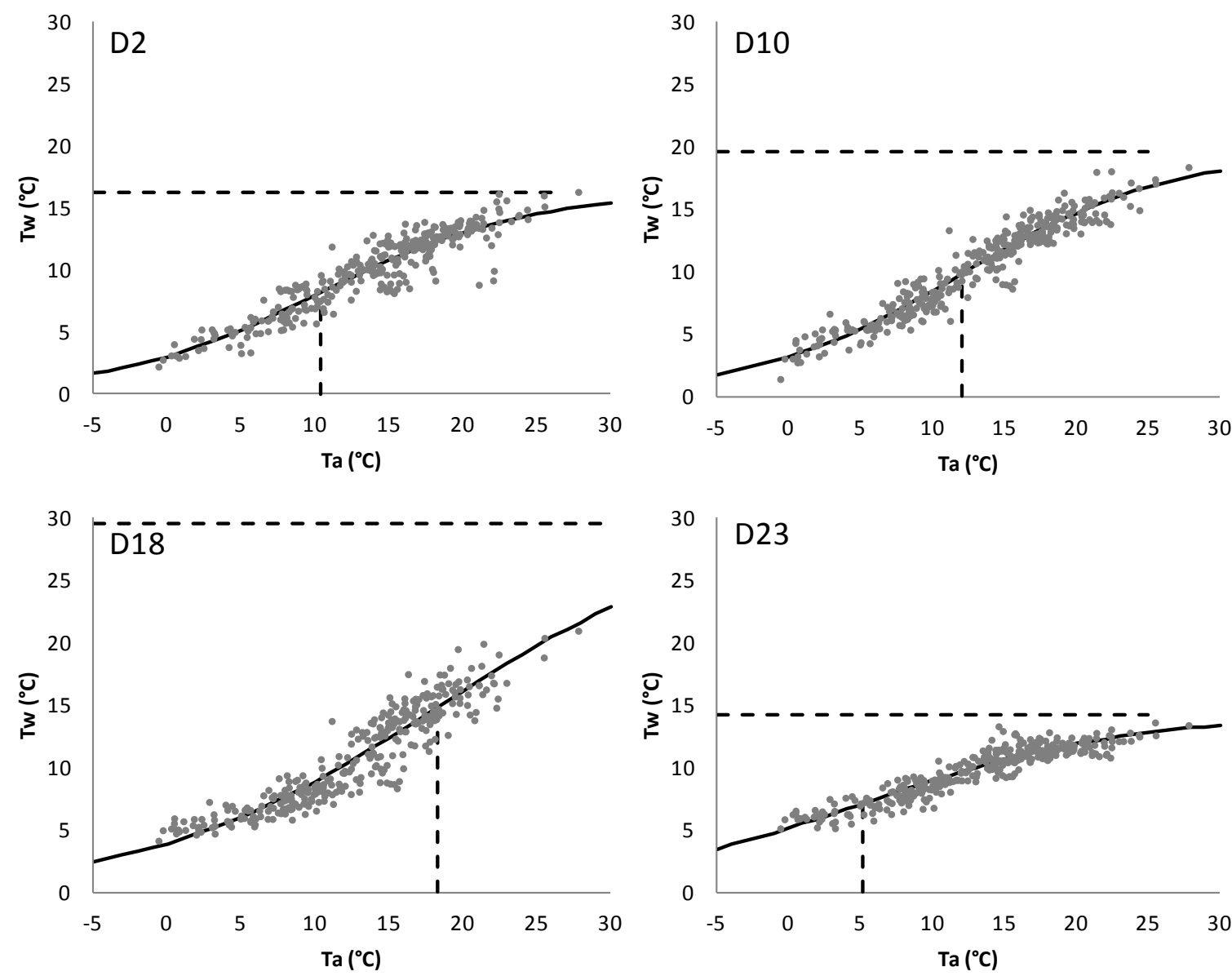
897 Figure 6: Comparison of residuals in predicted Tw (grey line) with observed Ta (black line) 898 for D4 (the best Dove model) and D17 (the weakest Dove model). Scatterplots (with line of 899 best fit) for predicted versus observed Tw are also shown.

900
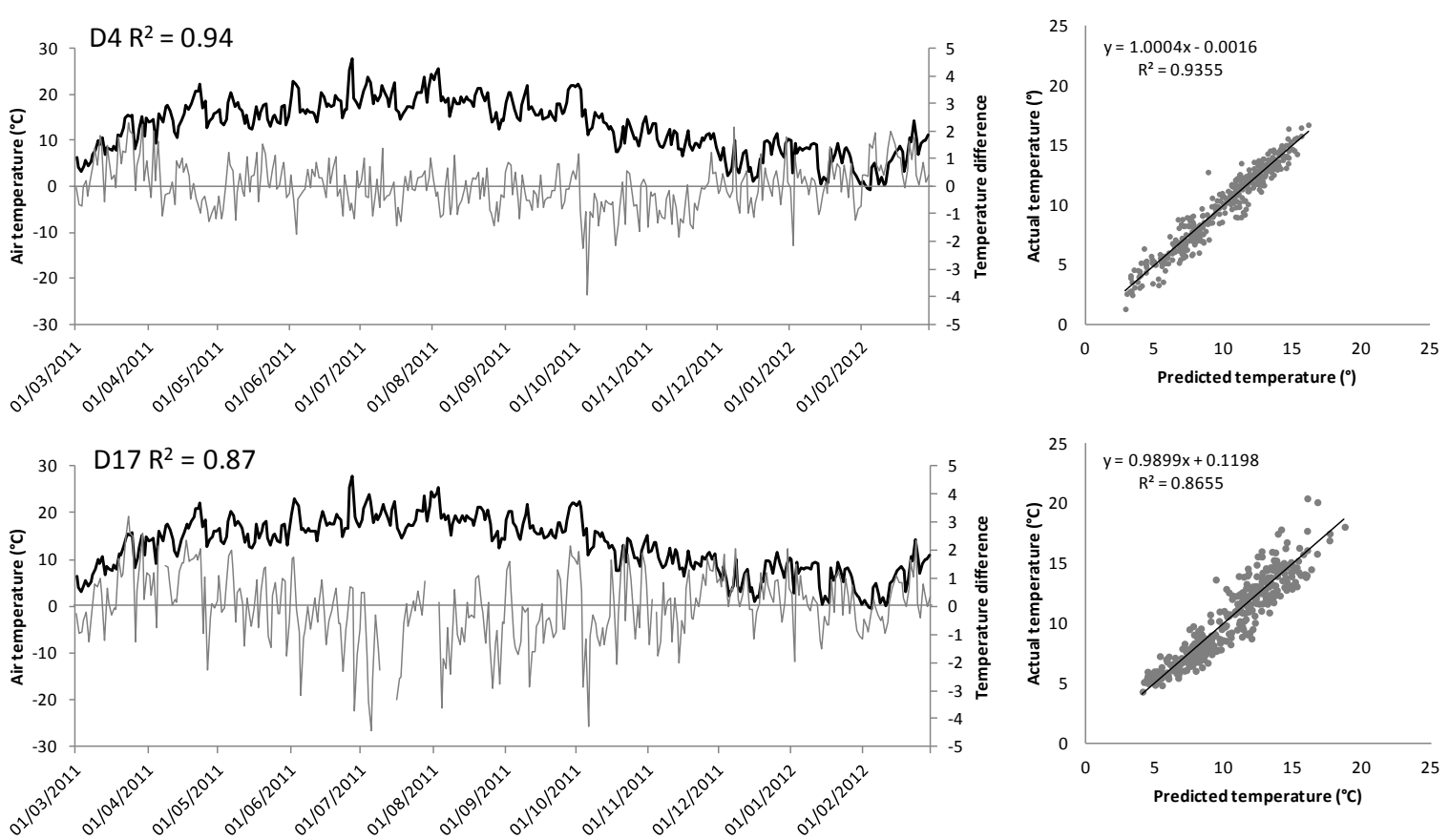
904 Figure 7: Linear correlation decay between Ta and Tw in (a) River Manifold and (b) Dove 905 with lag-interval (days). Each line represents a site. c) Spatial heterogeneity in autocorrelation 906 showing changes in $\mathrm{R}^{2}$ for logistic regression models with lagged and un-lagged Ta over 1, 2 907 and 3 days for the River Dove (grey circles) and Manifold (black squares). Negative changes 908 in the lower Dove reveal sites where lag-1 day Ta explains more variance in Tw than lag-0 909 Tа.

910
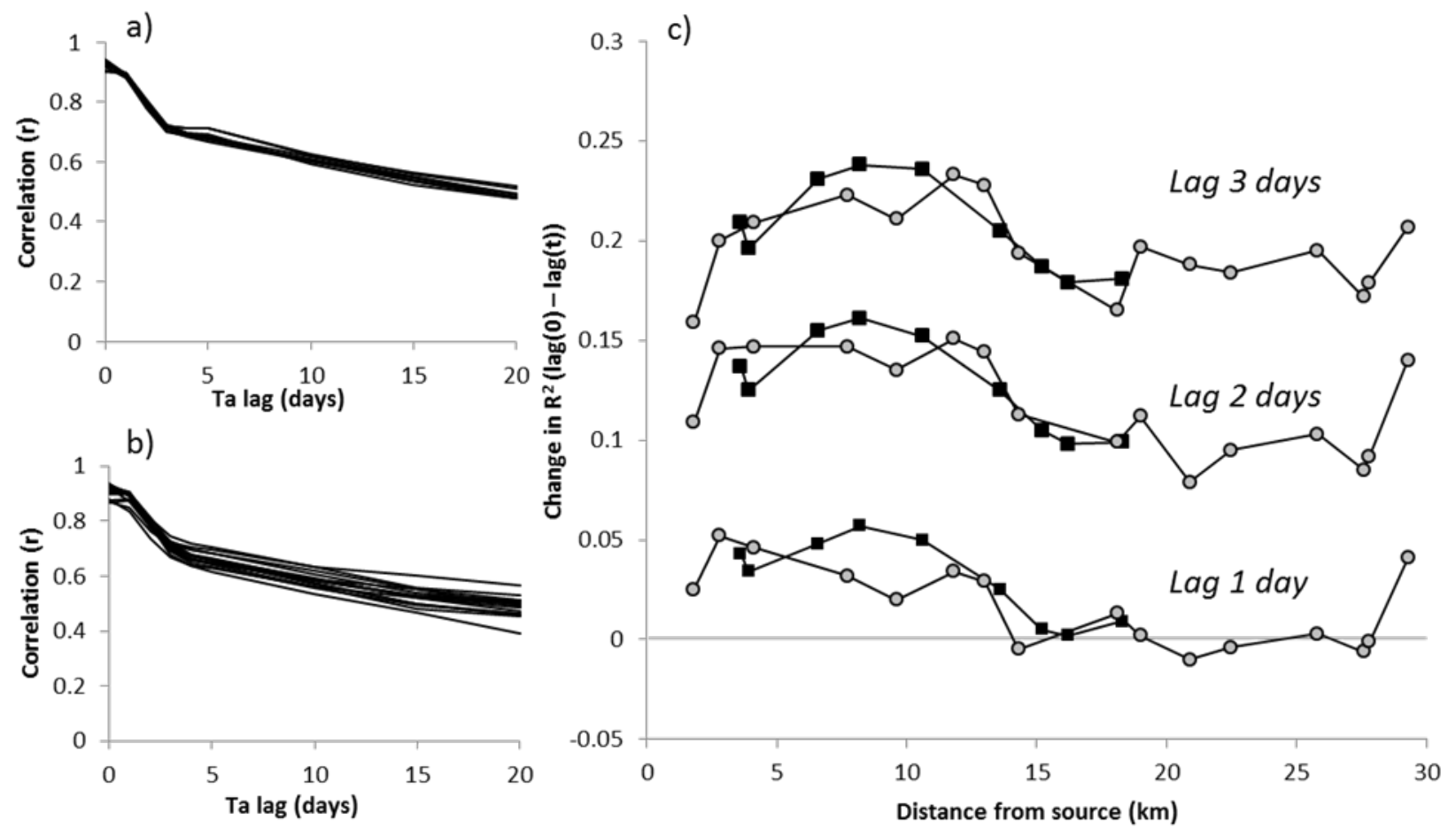
913 Figure 8: Annual mean daily-maximum Tw (upper row) and Tw range (lower row) with 914 distance from source for the Rivers Dove (left column) and Manifold (right column).

915
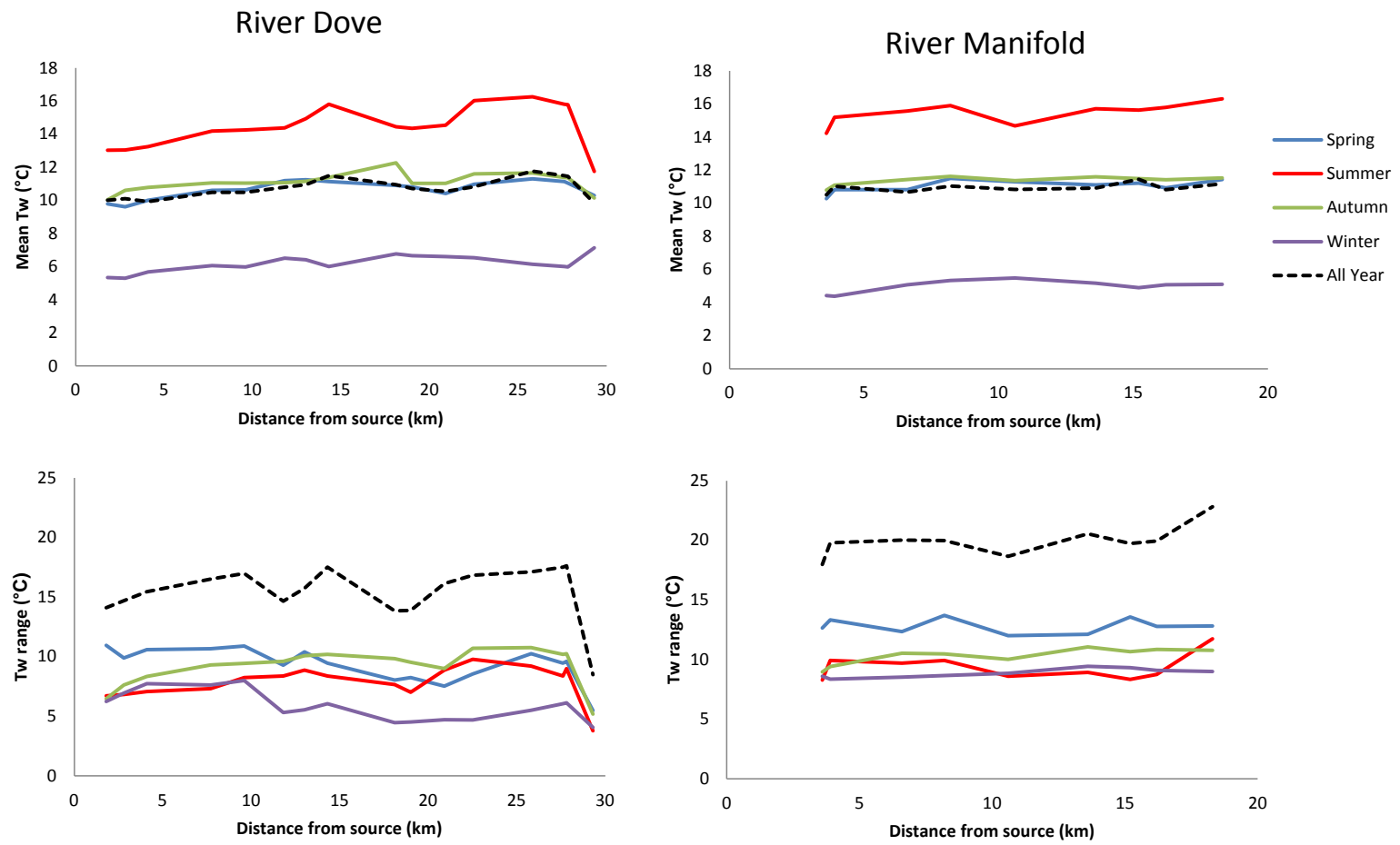
917 Figure 9: Relationship between local gamma parameter values of the logistic regression 918 models in the Dove (circles) and Manifold (squares) versus length (km) of upstream riparian 919 shade. The open circle denotes site D23, characterised by substantial groundwater flows.

920

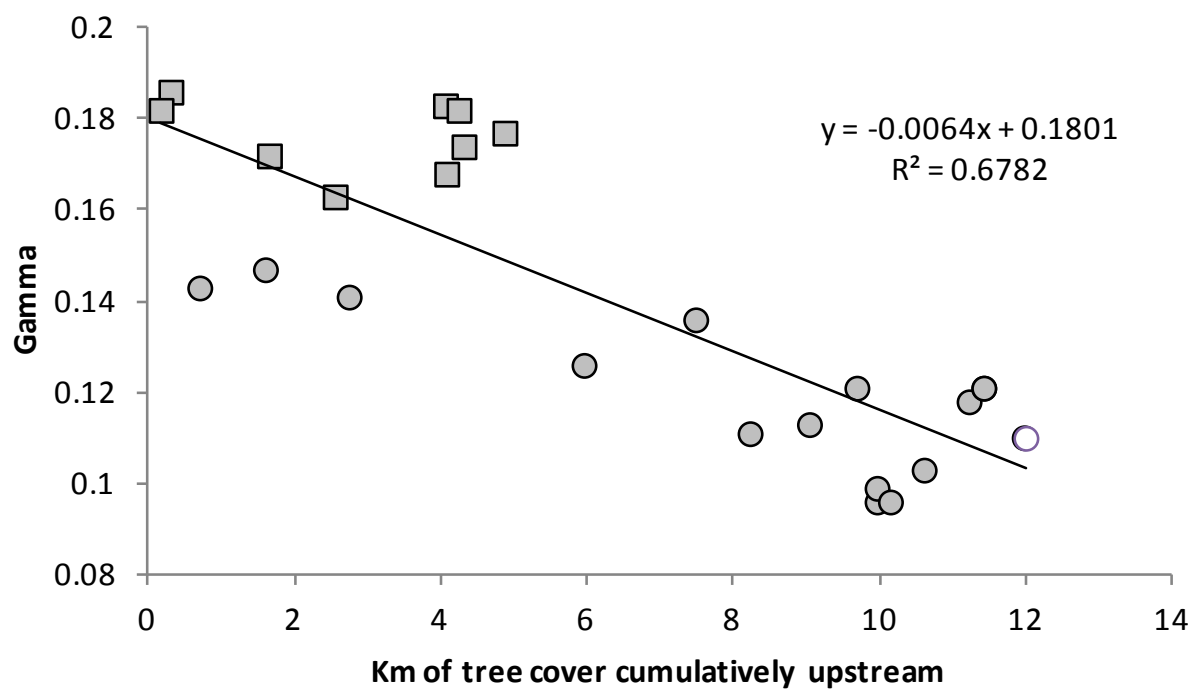

921

922

923 
924 Figure 10: The amount of explained variance $\left(\mathrm{R}^{2}\right)$ by regression models calibrated on non925 overlapping bi-monthly periods (MA = March to April, MJ = May to June, and so forth), 926 illustrating a weakening of the Ta - Tw relationship during summer months. Four sites are 927 shown, indicating a general decline in summer $\mathrm{R}^{2}$ with distance from source, noting that D23 928 is a site with substantial groundwater inputs (i.e., affected by both shading and spring flow). 929

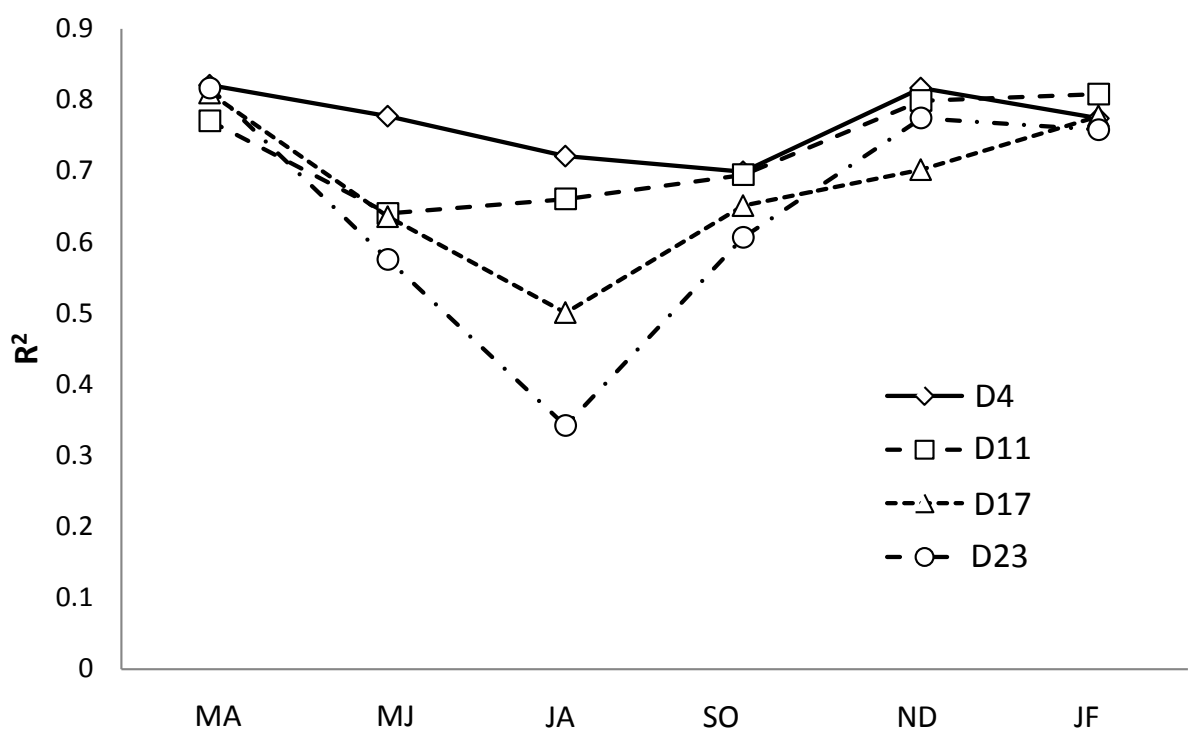

